\title{
Controls on phosphorus regeneration and burial during formation of eastern Mediterranean sapropels
}

\author{
Caroline P. Slomp ${ }^{\mathrm{a}, *}$, John Thomson ${ }^{\mathrm{b}}$, Gert J. de Lange ${ }^{\mathrm{a}}$ \\ a Department of Earth Sciences - Geochemistry, Utrecht University, P.O. Box 80021, 3508 TA Utrecht, The Netherlands \\ b Southampton Oceanography Centre, Empress Dock, Southampton SO14 3ZH, UK
}

Received 1 November 2001; received in revised form 29 April 2003; accepted 6 October 2003

\begin{abstract}
The carbon (C) and phosphorus (P) geochemistry of sapropels from four sites in the eastern Mediterranean Sea was determined to obtain more insight into the role of differences in sediment accumulation rates and bottom water anoxia on $\mathrm{P}$ regeneration and burial in sediments. Sediment $\mathrm{C}_{\text {org }} / \mathrm{P}_{\text {org }}$ (with org $=$ organic) ratios above Redfield indicate enhanced regeneration of $\mathrm{P}$ relative to $\mathrm{C}$ from organic matter during formation of the most recent sapropel S1 and a Pliocene sapropel (ODP-site 969E; i-282c). Release of P from Fe-oxides was relatively unimportant. Increased burial of Ca-P (authigenic carbonate fluorapatite and/or biogenic hydroxyapatite) occurred but was of minor importance compared to the enhanced $\mathrm{P}$ release from organic matter. For sapropel $\mathrm{S} 1, \mathrm{C}_{\text {org }} / \mathrm{P}_{\text {org }}$ and $\mathrm{C}_{\text {org }} / \mathrm{P}_{\text {reac }}$, (with reac $=$ reactive, defined as the sum of organic, Fe-bound, authigenic and biogenic Ca-P) ratios decreased with increasing sedimentation rate and oxygen exposure and decreasing water depth. Whether the water column in the deep basin was dysoxic/semi-euxinic (S1) or euxinic (Pliocene) does not appear to affect the estimated burial efficiencies of $\mathrm{P}_{\text {org }}$ and $\mathrm{P}_{\text {reac }}$. Enhanced $\mathrm{C}_{\text {org }}$ burial under the euxinic water column explains the much higher $\mathrm{C}_{\text {org }} / \mathrm{P}_{\text {org }}$ and $\mathrm{C}_{\text {org }} / \mathrm{P}_{\text {reac }}$ ratios in the Pliocene sapropel (on average $\sim 2860$ and $\sim 760$, respectively) compared to sapropel S1 (on average $\sim 530$ and $\sim 160$, respectively).
\end{abstract}

(C) 2003 Elsevier B.V. All rights reserved.

Keywords: phosphorus; redox; anoxic sediments; Mediterranean sapropels

\section{Introduction}

Phosphorus (P) is an essential nutrient for the growth of marine phytoplankton. On geological time scales, it is the limiting nutrient for global marine productivity (Holland, 1978; Broecker, 1982; Tyrell, 1999). P has also been found to limit productivity on shorter time scales in various ma-

\footnotetext{
* Corresponding author. Fax: +31-30-2535302.

E-mail address: slomp@geo.uu.nl (C.P. Slomp).
}

rine environments (Benitez-Nelson, 2000), including open ocean, oligotrophic areas in the North Atlantic and North Pacific (Cotner et al., 1997; Karl et al., 1997), the Baltic Sea (Granéli et al., 1990) and the eastern Mediterranean Sea (Krom et al., 1991).

Since burial in sediments is the only sink for $\mathrm{P}$ in the marine environment, changes in the burial rate of $\mathrm{P}$ can modify the $\mathrm{P}$ inventory in the bottom water. Provided there is sufficient vertical mixing to transport dissolved $\mathrm{P}$ from the bottom water to the surface water, this can affect primary 
productivity and carbon (C) cycling on both a regional (Slomp et al., 2002; Filippelli et al., 2003) and a global scale (Holland, 1978; Broecker, 1982; Van Cappellen and Ingall, 1994, 1996). The elemental cycles of $\mathrm{C}$ and $\mathrm{P}$ are coupled via the $\mathrm{C} / \mathrm{P}$ ratio of the marine phytoplankton and the $\mathrm{C} / \mathrm{P}$ ratio of the organic matter preserved in marine sediments. The $\mathrm{C} / \mathrm{P}$ ratio of marine phytoplankton is generally close to the Redfield ratios of 106 (Redfield et al., 1963) or 117 (Anderson and Sarmiento, 1994). The C/P ratio of organic matter buried in marine sediments $\left(\mathrm{C}_{\text {org }} / \mathrm{P}_{\text {org }}\right)$, in contrast, varies over a wide range $(50-4500$; Ingall and Van Cappellen, 1990; Ingall et al., 1993; Anderson et al., 2001). Values of $\mathrm{C}_{\text {org }} / \mathrm{P}_{\text {org }}$ below the Redfield ratio are mostly found in oxic, low sedimentation rate environments with low $\mathrm{C}_{\text {org }}$ concentrations. This has been attributed to errors in the $\mathrm{C}_{\text {org }}$ (e.g. Anderson et al., 2001) and $\mathrm{P}_{\text {org }}$ analyses (e.g. Mach et al., 1987) and to concentration of refractory detrital organic compounds enriched in $\mathrm{P}$ or of in situ synthesized bacterial remains (Ingall and Van Cappellen, 1990). Values of $\mathrm{C}_{\text {org }} / \mathrm{P}_{\text {org }}$ above the Redfield ratio indicate either a terrestrial source of organic matter (Ruttenberg and Goni, 1997) or preferential regeneration of $\mathrm{P}$ relative to $\mathrm{C}$ during organic matter decomposition. This preferential regeneration is most pronounced in sediments overlain by anoxic bottom waters (Ingall et al., 1993; Ingall and Jahnke, 1997; Van Cappellen and Ingall, 1994, 1997; Eijsink et al., 1997; Schenau and De Lange, 2001; Slomp et al., 2002) when it may be further augmented by phosphate release from Fe-oxides upon their reductive dissolution (e.g. Einsele, 1936; Mortimer, 1941; McManus et al., 1997; Colman and Holland, 2000). There are two feedback mechanisms, however. First, the P released from the organic matter can precipitate in the sediment as authigenic carbonate fluorapatite (CFA or $\mathrm{P}_{\text {auth }}$; e.g. Ruttenberg and Berner, 1993; Slomp et al., 1996a; Schenau et al., 2000; Filippelli, 2001). Second, enhanced burial of biogenic $\mathrm{Ca}-\mathrm{P}\left(\mathrm{P}_{\text {bio }}\right.$; fish debris, hydroxyapatite) can occur in sediments overlain by anoxic bottom waters (Schenau and De Lange, 2000; Slomp et al., 2002). Both Ca-P forms can act as a sink of reactive $\mathrm{P}\left(\mathrm{P}_{\text {reac }}\right)$, which is defined as the sum of organic, Fe-bound, authigenic and biogenic $\mathrm{P}$ (Ruttenberg, 1993). This makes it important to evaluate not only sediment $\mathrm{C}_{\text {org }} / \mathrm{P}_{\text {org }}$ ratios but also $\mathrm{C}_{\text {org }} /\left(\mathrm{P}_{\text {org+auth+bio }}\right)$ (Slomp et al., 2002) and $\mathrm{C}_{\text {org }} / \mathrm{P}_{\text {reac }}$ ratios (e.g. Anderson et al., 2001; Filippelli, 2001) to assess the potential effects of preferential regeneration of $P$ relative to $C_{\text {org }}$ on water column chemistry and marine productivity.

The type of sedimentary environment plays an important role in determining the regeneration and burial of $\mathrm{P}$ in marine sediments (e.g. Föllmi, 1996; Filippelli, 1997; Delaney, 1998). Key factors on short times scales include the redox conditions in the sediment and water column (Ingall et al., 1993; Ingall and Jahnke, 1994; Sundby et al., 1992; McManus et al., 1997; Slomp et al., 1998; Colman and Holland, 2000; Filippelli, 2001), the supply of $P$ to the sediment and its reactivity or solubility (e.g. Van Cappellen and Berner, 1988; Schenau and De Lange, 2001), the sediment accumulation rate (Ingall and Van Cappellen, 1990; Filippelli, 1997) and the rate of sediment mixing (e.g. Slomp et al., 1996a; Schenau et al., 2000). The relative importance of each of these factors in determining the $\mathrm{P}$ burial efficiency (BE, defined as the fraction of the deposited $\mathrm{P}$ that is buried in the sediment) in different types of marine sediments is still incompletely understood.

We expect that $\mathrm{P}$ burial efficiencies are lowest and enhanced regeneration of $\mathrm{P}$ relative to $\mathrm{C}$ is most pronounced in sedimentary environments where net sediment accumulation rates are low, sediment mixing is absent and both a major part of the water column and the sediment are dysoxic or anoxic. In such environments, $\mathrm{P}$ is preferentially released from organic matter in the water column and/or close to the sediment-water interface in the sediment. Release of $\mathrm{P}$ from reductively dissolving Fe-oxides may be an additional source of P. CFA formation is expected to be limited due to low porewater phosphate concentrations but biogenic Ca-P burial may be enhanced. This was shown to be the case for the most recent sapropel S1 in the deep-basin of the eastern Mediterranean Sea (Slomp et al., 2002).

In this paper, we use the $\mathrm{C}$ and $\mathrm{P}$ geochemistry for sapropels from four sites in the eastern Med- 


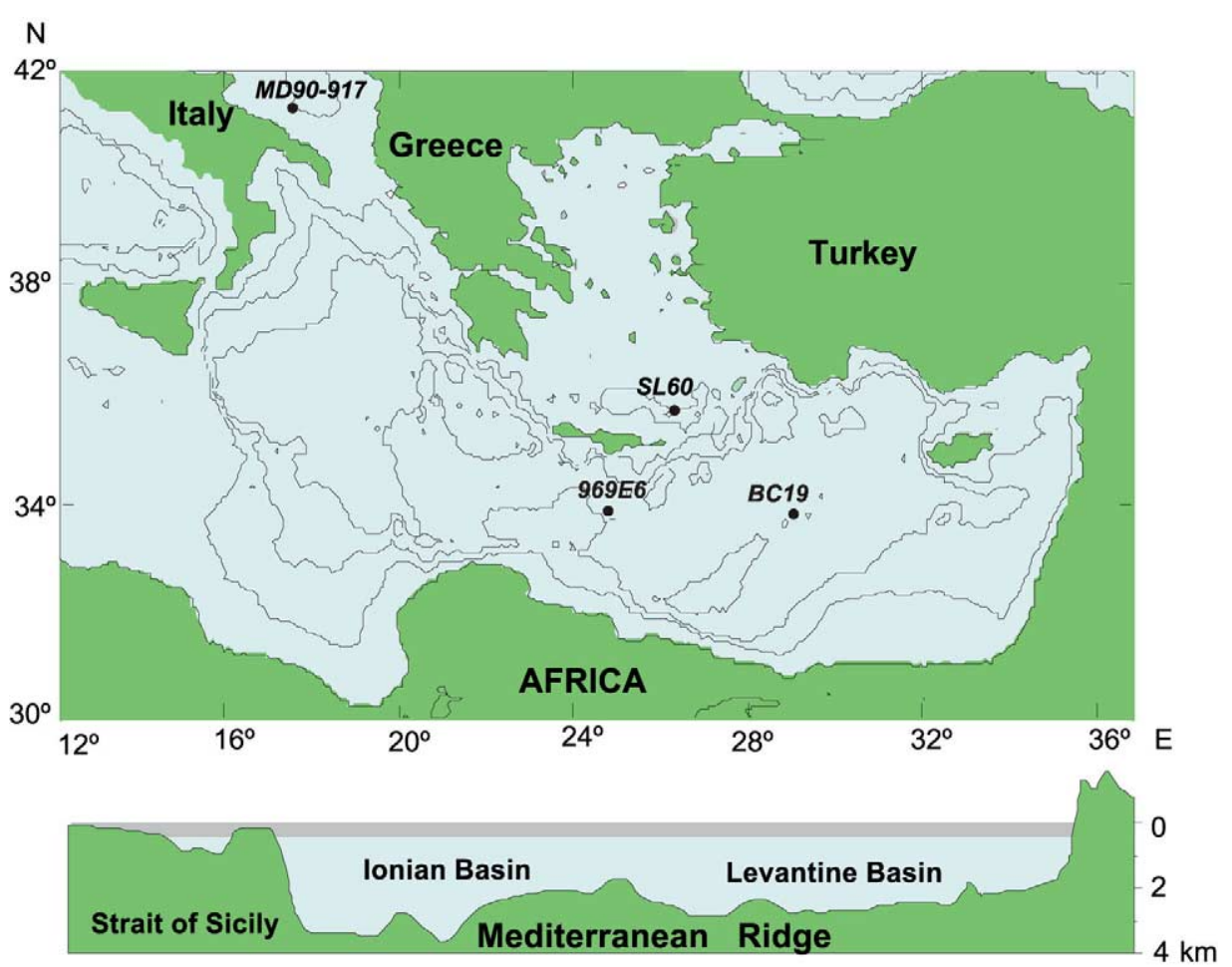

Fig. 1. Sample locations of the four cores studied.

Table 1

Site and sapropel characteristics

\begin{tabular}{lllll}
\hline & Box core & Piston core & Piston core & $\begin{array}{l}\text { ODP-core } \\
\text { MD90-917 }\end{array}$ \\
& BC19 & SL60 & A69 $\mathrm{E}^{\mathrm{a}}$ \\
\hline Location & Levantine Basin & SE Aegean Sea & Adriatic Sea & Levantine Basin \\
Latitude & $33^{\circ} 47.85^{\prime} \mathrm{N}$ & $35^{\circ} 399^{\prime} 69^{\prime} \mathrm{N}$ & $41^{\circ} 18^{\prime} \mathrm{N}$ & $33^{\circ} 50.5^{\prime} \mathrm{N}$ \\
Longitude & $28^{\circ} 36.50^{\prime} \mathrm{E}$ & $26^{\circ} 34.99^{\prime} \mathrm{E}$ & $17^{\circ} 37^{\prime} \mathrm{E}$ & $24^{\circ} 53.0^{\prime} \mathrm{E}$ \\
Cruise & Marflux-I MD69 & Medineth & $-^{\mathrm{b}}$ & ODP Leg 160 \\
Research Vessel & Marion Dufresne & Logachev & $-^{\mathrm{b}}$ & Joides resolution \\
Water depth $(\mathrm{m})$ & 2750 & 1522 & 1010 & 2201 \\
Sedimentation rate $(\mathrm{cm} / \mathrm{kyr})^{\mathrm{c}}$ & 2.9 & 8.4 & $\sim 10$ & 3 \\
Sapropel & S1 & S1 & S1 & i-282c \\
Epoch & Holocene & Holocene & Pliocene \\
\hline
\end{tabular}

a Section 160-969E06H-6 from 50.7 mbsf, insolation cycle i-282c.

b Sampled at the core archive at the Laboratoire des Sciences du Climat et de L'Environnement, Gif-sur-Yvette.

${ }^{c}$ Sources of sedimentation rates: BC19: Slomp et al. (2002); SL60: estimated from thickness of sapropel in core SL60 and radiocarbon dates for the S1 boundaries in core LC21 from the same site (Mercone et al., 2000, 2001); MD90-917: based on radiocarbon dates of Mercone et al. (2000), taking into account that the Calypso corer extends upper core sections by an average factor of 2 without affecting the stratigraphy (Thouveny et al., 2000); 969E: Emeis et al. (1996). 
iterranean Sea to obtain more insight into the factors controlling $\mathrm{P}$ regeneration and burial in slowly accumulating sediments overlain by dysoxic or anoxic bottom waters. We look at the combined effect of differences in sediment accumulation rates and oxygen exposure by comparing $\mathrm{C}_{\text {org }} / \mathrm{P}_{\text {org }}$ and $\mathrm{C}_{\text {org }} / \mathrm{P}_{\text {reac }}$ ratios for 3 sites containing sapropel $\mathrm{S} 1$ (dysoxic/semi-euxinic bottom water; with oxygen exposure increasing with decreasing water depth; see Section 2). We study the effect of different water column redox conditions by comparing $\mathrm{C}_{\text {org }} / \mathrm{P}_{\text {org }}$ and $\mathrm{C}_{\text {org }} / \mathrm{P}_{\text {reac }}$ ratios and $\mathrm{C}$ and $\mathrm{P}$ burial efficiencies for the most recent sapropel S1 to that of a Pliocene sapropel (euxinic bottom water) at two sites with comparable sedimentation rates. We conclude with a brief discussion of the general implications of our findings.

\section{Materials and methods}

Samples for box and piston cores from four locations in the eastern Mediterranean Sea were selected for this study (Fig. 1; Table 1). Sedimentation rates range from 2.9 to $\sim 10 \mathrm{~cm} / \mathrm{kyr}$. The general geochemistry of the sediment at all of these sites has been described extensively in the past (e.g. BC19: Slomp et al., 2002; SL60 (LC21-site) and MD90-917: Mercone et al., 2000, 2001; 969E: Bosch et al., 1998; Passier and De Lange, 1998; Passier et al., 1999a,c; Nijenhuis and De Lange, 2000).

Sapropels in the eastern Mediterranean Sea (including the SW-Aegean and Adriatic) are the result of climatic changes which led to periods of decreased circulation, increased surface water productivity, dysoxic or anoxic bottom waters and increased preservation of organic matter (Calvert et al., 1992; Rohling, 1994; Thomson et al., 1999). Sapropel S1 was deposited between 6.0 and 9.5 kyr BP (Mercone et al., 2000) and is relatively organic-poor (up to $4 \mathrm{wt} \% \mathrm{C}_{\text {org }}$ ). That the bottom water was dysoxic or semi-euxinic during S1 formation has been deduced from, e.g. the trace metal, Fe and $\mathrm{S}$ geochemistry, abundances of benthic foraminifera, evidence for occasional bioturbation and preservation efficiencies of $\mathrm{C}_{\text {org }}$ in this sapropel (Passier et al., 1999c; Mercone et al., 2001;
Slomp et al., 2002). There is a close linear relation between $\mathrm{C}_{\text {org }}$ and water depth during sapropel $\mathrm{S} 1$, which has been explained as the result of a decrease in availability of oxygen in the water column with water depth (Murat and Got, 2000). Observed abundances of oxiphilic benthic foraminifera support such a trend of bottom water oxygen with water depth and indicate that bottom water anoxia during S1 times may have been spatially restricted and/or of an intermittent nature, particularly at shallower sites (Casford et al., 2003). The Pliocene sapropel has an age of 2.943 Ma (Lourens et al., 1996; Passier et al., 1999a) and is laminated and extremely organic-rich (up to $27 \mathrm{wt} \% \mathrm{C}_{\text {org }}$ ). The presence of specific molecular fossils and the trace metal, $\mathrm{Fe}$ and $\mathrm{S}$ geochemistry of this sapropel (Bosch et al., 1998; Passier et al., 1999a) provide evidence for its deposition under a euxinic (i.e. sulfide-rich) water column that reached into the photic zone. The organic matter in these sapropels is predominantly of marine origin (Emeis et al., 1996; Bosch et al., 1998; Bouloubassi et al., 1999).

Sediment samples $(0.5$ and $1 \mathrm{~cm}$ depth resolution) were freeze-dried and ground in an agate mortar (BC19, SL60, 969E) or in a tungsten carbide swing mill (MD90-917). For cores BC19, SL60 and 969E, total concentrations of Al, S, $\mathrm{Ba}, \mathrm{Ca}$ and $\mathrm{P}$ were determined after digestion in a mixture of $\mathrm{HF}, \mathrm{HNO}_{3}$ and $\mathrm{HClO}_{4}$ and final solution in $1 \mathrm{M} \mathrm{HCl}$ using ICP-OES (Perkin Elmer Optima 3000). For core 969E, Ba in sapropel samples was determined separately in solutions prepared by the same procedure but using only $40 \mathrm{mg}$ of sample to prevent $\mathrm{BaSO}_{4}$ precipitation. $\mathrm{CaCO}_{3}$ concentrations were calculated from total $\mathrm{Ca}$ contents. $\mathrm{Ca}$ in clays has been shown to account for less than $1 \%$ of total $\mathrm{Ca}$ and thus is negligible (Rutten, 2002). The reproducibility of the measurements was monitored by including laboratory standards. The relative error in the analysis was $<5 \%$ for all elements. $\mathrm{C}_{\text {org }}$ was determined on a Fisons Instruments CNS NA 1500 analyzer. Inorganic $\mathrm{C}$ was removed prior to the analysis by shaking the sample with $1 \mathrm{M} \mathrm{HCl}$ twice $(12 \mathrm{~h}$ and $4 \mathrm{~h})$. The sample was then rinsed twice with demineralized water, freeze-dried and ground in an agate mortar. $\mathrm{C}_{\text {org }}$ contents were 
corrected for carbonate weight loss during the $\mathrm{HCl}$ dissolution step. The relative error in the analysis was less than $1 \%$.

For core MD90-917, total concentrations of Al, $\mathrm{S}, \mathrm{Ba}$ and $\mathrm{Mn}$ were determined using a Philips PW1400 automatic sequential wavelength dispersive X-ray fluorescence spectrometer on samples prepared either as pressed powder pellets or as lithium meta-tetraborate fusion discs. $\mathrm{C}_{\text {org }}$ and $\mathrm{CaCO}_{3}$ were determined coulometrically via the release of $\mathrm{CO}_{2}$. Further analytical details are given by Mercone et al. (2001). Total concentrations of $\mathrm{P}$ of a selected number of samples (19) were determined after digestion in a mixture of $\mathrm{HF}$, $\mathrm{HNO}_{3}$ and $\mathrm{HClO}_{4}$ and final solution in $1 \mathrm{M}$ $\mathrm{HCl}$ using ICP-OES (Perkin Elmer Optima 3000).

Sediment $\mathrm{P}$ forms in selected samples from cores BC19, SL60, MD90-917 and 969E were determined using a sequential extraction procedure modified from that of Ruttenberg (1992) by Slomp et al. (1996a). Briefly, inorganic sediment $\mathrm{P}$ was fractionated into Fe-bound $\mathrm{P}$, authigenic+ biogenic $\mathrm{Ca}-\mathrm{P}$ and detrital Ca-P. Fe-bound $\mathrm{P}$ was determined as the sum of the $\mathrm{P}$ extracted with citrate-dithionite-bicarbonate (CDB: $0.30 \mathrm{M} \mathrm{Na}$ citrate, $1.0 \mathrm{M} \mathrm{NaHCO}_{3}$ and $0.5 \mathrm{~g}$ of Na-dithionite in $22.5 \mathrm{ml}$ of citrate bicarbonate solution, $\mathrm{pH}=7.3,8 \mathrm{~h}, 20^{\circ} \mathrm{C}$ ) and a subsequent wash step with $1 \mathrm{M} \mathrm{MgCl}$. The sediment residue was then rinsed with $1 \mathrm{M}$ Na-acetate buffer $(\mathrm{pH}=4,6 \mathrm{~h}$, $20^{\circ} \mathrm{C}$ ) and a $1 \mathrm{M} \mathrm{MgCl}_{2}$ wash solution. Authigenic+biogenic Ca-P was calculated as the sum of the $\mathrm{P}$ extracted in these last two steps. The sediment residue was then treated with $1 \mathrm{M} \mathrm{HCl}(24 \mathrm{~h}$, $20^{\circ} \mathrm{C}$ ) and the amount of extracted $\mathrm{P}$ was used as a measure of detrital Ca-P. With the exception of core MD90-917, all extractions were carried out in duplicate. $\mathrm{P}_{\text {org }}$ was determined non-sequentially as the difference between total $\mathrm{P}$ and $1 \mathrm{M} \mathrm{HCl}$ extractable $\mathrm{P}(24 \mathrm{~h})$. Inorganic $\mathrm{P}$ concentrations determined as the sum of Fe-bound $\mathrm{P}$, authigenic $\mathrm{P}$ and detrital Ca-P were approximately equal to $\mathrm{P}$ concentrations obtained with $1 \mathrm{M} \mathrm{HCl}$ in the onestep procedure (linear regression, slope $=0.997$; $r^{2}=0.79$ ).

The $\mathrm{P}, \mathrm{Fe}$ and $\mathrm{Mn}$ concentrations in the $\mathrm{CDB}$ solutions were measured using ICP-OES (Spectro Analytical Instruments; detection limits for P, Fe and $\mathrm{Mn}$ were $0.05,0.03$ and $0.03 \mathrm{mg} / \mathrm{l}$, respectively). All other $\mathrm{P}$ analyses were carried out using a Perkin Elmer spectrophotometer with the method of Strickland and Parsons (1972). The matrix of the blanks and standards matched the matrix of each sample solution analyzed. A reference sample was included in each extraction procedure and the relative error in the analysis ranged from $\sim 5$ to $30 \%$, with the highest values for the $\mathrm{P}$ forms with the lowest concentration. The relative error of the individual $\mathrm{P}$ extractions was generally $\sim 5 \%$, with the exception of the CDB-step $(\sim 10 \%)$. $\mathrm{CDB}$-extractable Fe was used as a measure of the $\mathrm{Fe}$ bound in $\mathrm{Fe}$ oxides and $\mathrm{FeS}$ (Slomp et al., 1996b).

\section{Results}

\subsection{General sediment geochemistry}

Cores BC19 and SL60 contain an ash layer which is identified as being from the Minoan eruption of Santorini at $3.6 \mathrm{kyr}$ BP (Fig. 2; Bruins and Van der Plicht, 1996). In all cores, the dark-colored visual sapropel is characterized by $\mathrm{C}_{\text {org }}(0.6-27 \%)$ and $\mathrm{S}$ (ca. $\left.0.5-5 \%\right)$ concentrations that are higher than in the surrounding sediment. In cores SL60 and MD90-917, sapropel S1 consists of two dark-colored lobes, separated by a light-colored section. Maximum $\mathrm{C}_{\text {org }}$ contents in the Pliocene sapropel in core $969 \mathrm{E}$ are up to a factor 24 higher than values observed for the S1 sapropel. The depth profile of $\mathrm{Ba} / \mathrm{Al}$ in core $\mathrm{BC} 19$ shows a Gaussian-shape starting at the base of the visual sapropel and returning to baseline values at ca. $5.5 \mathrm{~cm}$ above the top of the visual sapropel. $\mathrm{Ba} / \mathrm{Al}$ ratios in cores SL60 and MD90-917 are elevated in the two dark-colored lobes of the sapropel. High CDB-Fe/total Al ratios are found above the visual sapropel in cores BC19 and SL60 and in the visual sapropel of cores MD90917 and 969E. Apart from the diagenetic $\mathrm{CaCO}_{3}$ peak in the sapropel of core MD90-917 (consisting of mixed [Ca, $\mathrm{Mn}(\mathrm{II}), \mathrm{Mg}$ ] carbonate; Mercone et al., 2001), $\mathrm{CaCO}_{3}$ concentrations in the ash layer and in the sapropels are generally lower than in the surrounding sediment. The sapropel in 

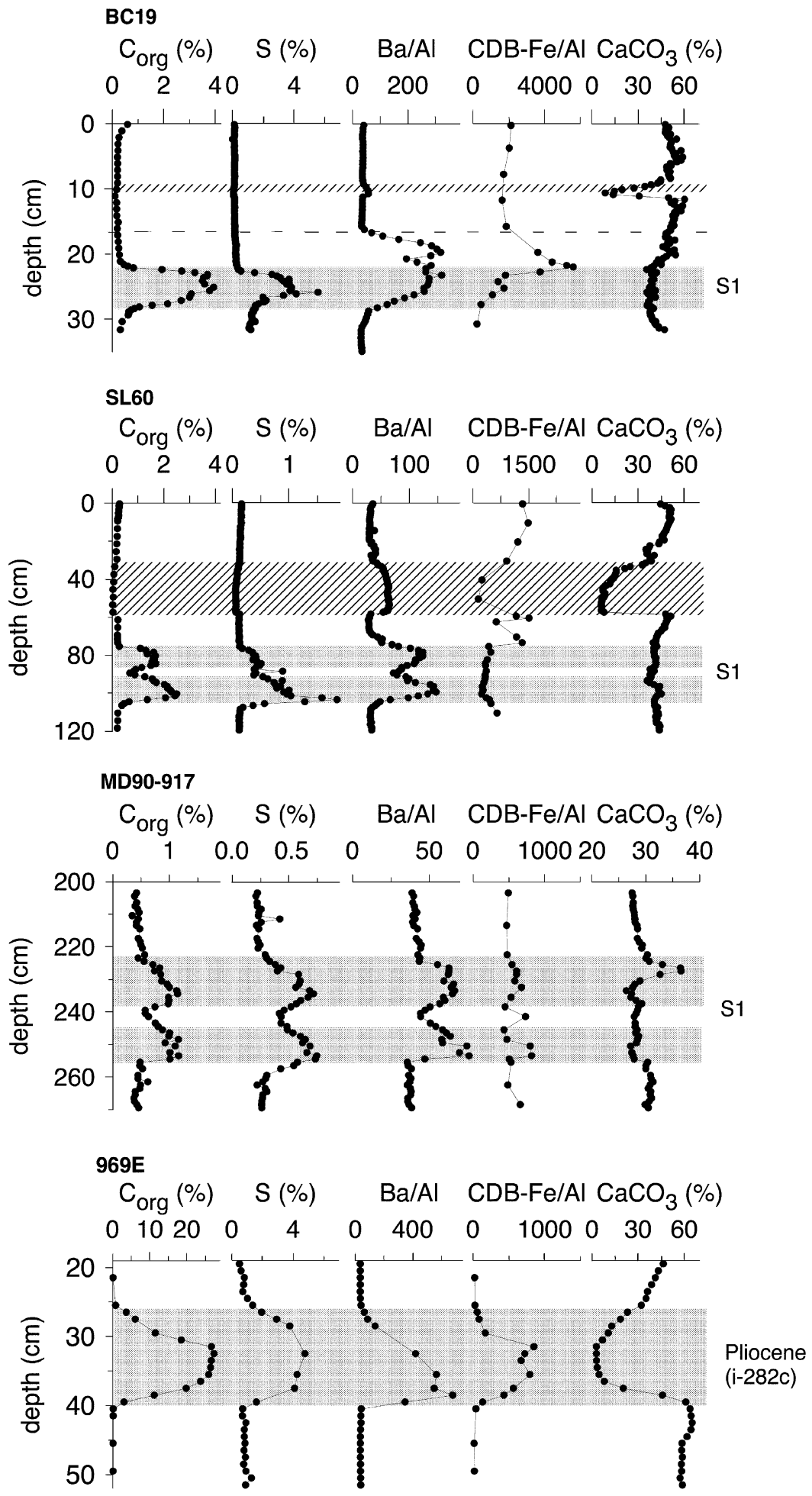
core $969 \mathrm{E}$ is particularly poor in $\mathrm{CaCO}_{3}$ due to the absence of both benthic and planktonic foraminifera (Nijenhuis and De Lange, 2000).

\subsection{Solid phase $P$ forms}

Total $\mathrm{P}$ concentrations in all non-sapropel intervals are generally relatively constant at $10-16$ $\mu \mathrm{mol} \mathrm{g}{ }^{-1}$ (Fig. 3; Table 2). All sapropels are enriched in $\mathrm{P}$ relative to surrounding layers. In cores BC19 and SL60, additional enrichments, which consist of Fe-bound $\mathrm{P}$, occur at the top of the visual sapropel $\mathrm{S} 1 . \mathrm{P}_{\text {org }}$ concentrations in the sapropels are equal to or up to a factor $\sim 5$ higher than in the surrounding sediment. The sapropels are all locally enriched in authigenic+biogenic $\mathrm{Ca}-$ $\mathrm{P}$. In core $\mathrm{BC} 19$, the enrichment can be totally attributed to biogenic $\mathrm{P}$, as was shown by Slomp et al. (2002) using an extraction procedure specific for biogenic P (Schenau and De Lange, 2000). The enrichment in Fe-bound $\mathrm{P}$ in 4 samples of the Pliocene sapropel is most likely an artefact of the CDB-extraction. When $\mathrm{CaCO}_{3}$ concentrations are low, as is the case for these samples (Fig. 2), some fish debris may dissolve in CDBsolutions (Williams et al., 1980; Schenau and De Lange, 2000; Slomp, unpubl. results). Calculated Fe-bound $\mathrm{P}$ and authigenic+biogenic $\mathrm{P}$ concentrations assuming the $\mathrm{Fe}$-bound $\mathrm{P}$ enrichment is actually biogenic $\mathrm{P}$ are shown in Fig. 3 and Table 2. Detrital $\mathrm{P}$ concentrations in all cores are low and show little variation with depth.

\section{3. $C$ and $P$ ratios and burial fluxes}

$\mathrm{C}_{\text {org }} / \mathrm{P}_{\text {org }}$ ratios in non-sapropel layers, i.e. in the sediment that was deposited under oxic conditions, range from 6 to 183 (Fig. 4; Table 2). The average ratio calculated from burial fluxes after $\mathrm{S} 1$ times for core $\mathrm{BC} 19$ is 86 (Table 3). In the $\mathrm{S} 1$ and Pliocene sapropels, $\mathrm{C}_{\text {org }} / \mathrm{P}_{\text {org }}$ ratios are generally significantly higher and range from 75 to 1114 and from 870 to 4432 , respectively. $\mathrm{C}_{\mathrm{org}} /$ $\mathrm{P}_{\text {reac }}$ ratios in the $\mathrm{S} 1$ and Pliocene sapropel (Fig. 4; Table 2) range from 20 to 255 and 248 to 1273 , respectively, and thus are lower than $\mathrm{C}_{\text {org }} / \mathrm{P}_{\text {org }}$ ratios. Samples from the light colored section of the S1 sapropel in cores SL60 and MD90-917 have lower $\mathrm{C}_{\text {org }} / \mathrm{P}_{\text {org }}$ and $\mathrm{C}_{\text {org }} / \mathrm{P}_{\text {reac }}$ ratios than the dark colored parts of the sapropel (Fig. 4; Table 2).

\section{Discussion}

\subsection{The position of the SI and Pliocene sapropels and the redox front}

The zone of elevated Ba concentrations (Fig. 2) indicates the original thickness of the S1-sapropel. The $\mathrm{Ba}$ is in the form of biogenic barite and has been shown to be a reliable guide to the position of sapropels in which the initial high $\mathrm{C}_{\text {org }}$ contents have been partly or completely removed by oxidation (Van Santvoort et al., 1996, 1997; Langereis et al., 1997; Thomson et al., 1999). In core $\mathrm{BC} 19$, part of $\mathrm{S} 1$ is removed due to post-depositional downward oxidation (Van Santvoort et al., 1996; Slomp et al., 2002). The present-day redox front is located at the top of the visual sapropel and the Fe-oxide and $\mathrm{Fe}$-bound $\mathrm{P}$ peaks are currently forming through precipitation of upward diffusing $\mathrm{Fe}^{2+}$ and $\mathrm{HPO}_{4}^{2-}$ (porewater profiles in Slomp et al., 2002).

The similar trends in the $\mathrm{C}_{\text {org }}$ and $\mathrm{Ba}$ profiles in cores SL60, MD90-917 and 969E indicate that in these cores the sapropel is unaffected by post-depositional oxidation. The interruption of sapropel S1 in core SL60 and MD90-917 centered on 7500 radiocarbon convention years (Mercone et al., $2000,2001)$ is believed to be due to a short-term cooling event in which the bottom water ventilation and oxygenation in the Adriatic and Aegaen Seas increased temporarily (De Rijk et al., 1999;

Fig. 2. Depth profiles of $\mathrm{C}_{\text {org }}(\%), \mathrm{S}(\%), \mathrm{Ba} / \mathrm{Al}(\mathrm{ppm} / \%), \mathrm{CDB}-\mathrm{Fe} /$ total $\mathrm{Al}(\mathrm{ppm} / \%)$ and $\mathrm{CaCO}_{3}(\%)$ for cores $\mathrm{BC} 19$, SL60, MD90-917 and 969E. The visual sapropel is indicated by the shaded area. The Santorini ash layer in cores BC19 and SL60 is indicated by the hatched area. The dashed line in the BC19 plots indicates the top of the original sapropel. $\mathrm{Ba}$ and $\mathrm{Fe}$ profiles are normalized to $\mathrm{Al}$ to correct for fluctuations in carbonate content. For core $969 \mathrm{E}$ only the depth in the section is indicated. 


\section{BC19}

Tot. $\mathrm{P} \quad$ Fe-bound $\mathrm{P} \quad$ Org. $\mathrm{P} \quad$ Auth. + Bio. $\mathrm{P}$ Detr. $\mathrm{P}$

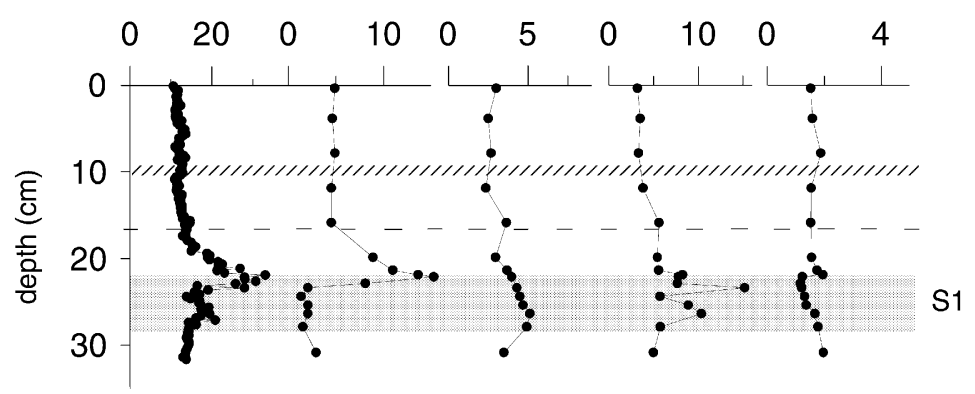

SL60

Tot. $\mathrm{P} \quad$ Fe-bound $\mathrm{P} \quad$ Org. $\mathrm{P} \quad$ Auth. + Bio. $\mathrm{P}$ Detr. $\mathrm{P}$ $\begin{array}{llllllllll}12 & 160 & 4 & 0 & 4 & 0 & 10 & 0 & 2 & 4\end{array}$

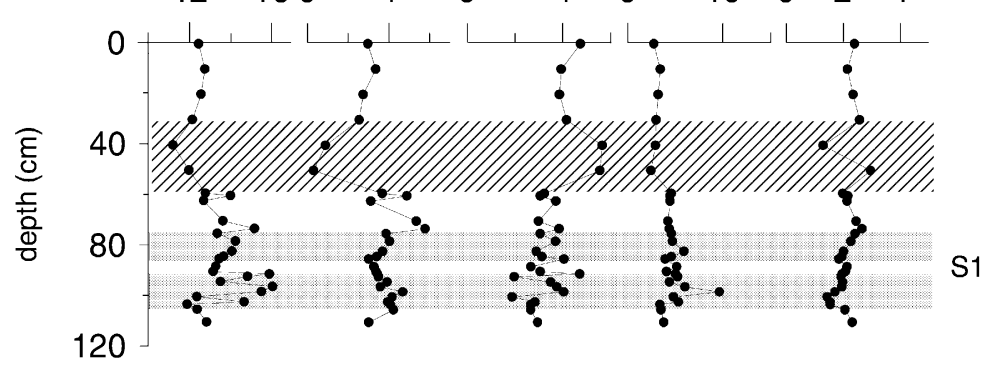

\section{MD90-917}

Tot. $\mathrm{P} \quad$ Fe-bound $\mathrm{P} \quad$ Org. $\mathrm{P} \quad$ Auth. + Bio. $\mathrm{P}$ Detr. $\mathrm{P}$

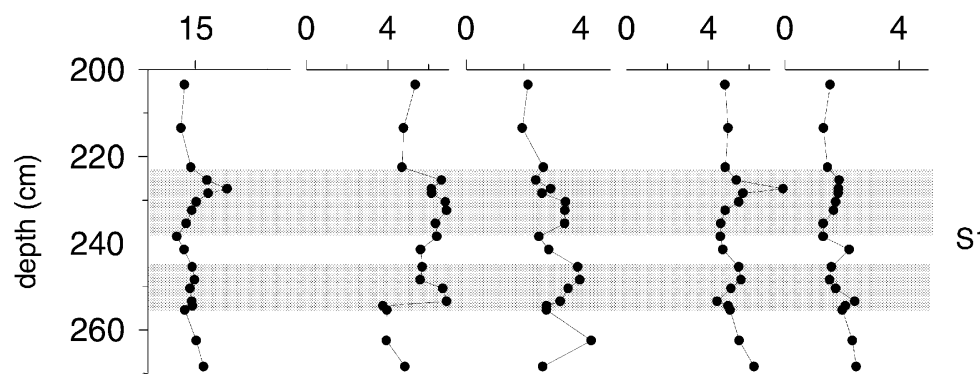

969E

Tot. $\mathrm{P} \quad$ Fe-bound $\mathrm{P} \quad$ Org. $\mathrm{P}$ Auth. + Bio. $\mathrm{P}$ Detr. $\mathrm{P}$

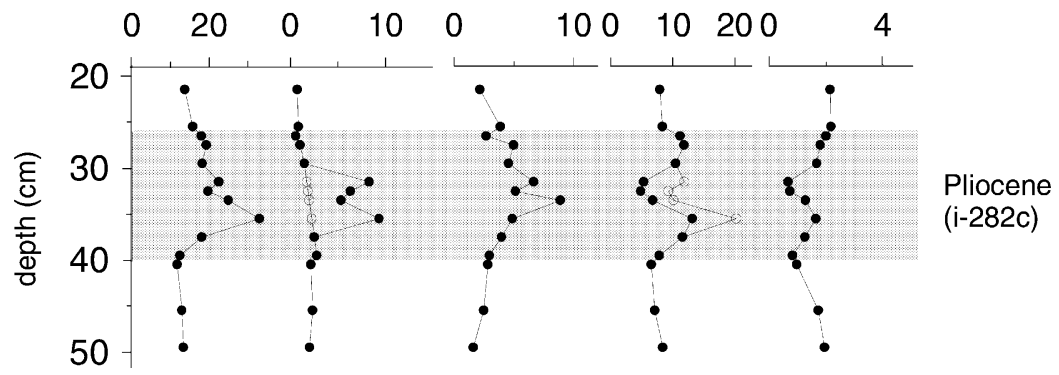


Mercone et al., 2000, 2001; Casford et al., 2003). No porewater data are available for these cores, therefore it is not possible to determine the exact position of the present-day redox front in the sediment above the sapropel. Since the redox front is expected to move upwards upon sediment accumulation, we expect that in core SL60 the lower Fe-oxide and Fe-bound $\mathrm{P}$ enrichments are relicts of a former redox front and are slowly dissolving. The enrichments directly below the ash layer are then most likely actively forming. In cores MD90-917 and 969E, no Fe enrichment is present above the sapropel. Either an oxidation front was never present above these sapropels or the oxidized $\mathrm{Fe}$ was reduced and diffused upwards away from the sapropel. The enrichment of CDB$\mathrm{Fe}$ in the sapropel of both cores can be attributed to dissolution of Fe-sulfides, as was shown for core 969E by Passier and De Lange (1998) previously. The amount of CDB-Fe in these enrichments is only $\sim 5 \%$ of the total Fe in these sapropels.

Detailed study of both the S1 and Pliocene sapropel has shown that most of the diagenetic alteration of the visual, unoxidized sapropel has taken place during and shortly after its formation. Mn and $\mathrm{Fe}$ oxide reduction and methanogenesis in the sapropel are severely restricted due to the absence of significant amounts of reactive oxides (Passier and De Lange, 1998; Slomp et al., 2002) and due to the abundant presence of sulfate in the porewater (Emeis et al., 1996), respectively. The S and $\mathrm{Fe}$ geochemistry indicates that post-burial sulfate reduction and pyrite formation have been absent (S1) or limited (Pliocene) (Passier and De Lange, 1998; Passier et al., 1999a,b,c). Apparently, the reactivity of the organic matter is too low to sustain substantial rates of sulfate reduction (De Lange et al., 1994; Passier and De Lange, 1998). In the absence of significant active organic matter decomposition, the chemical signals in the visual sapropel can be used to reconstruct the diagenesis of $\mathrm{P}$ during sapropel formation.

\subsection{Reconstruction of the sedimentary $P$ cycle during sapropel formation}

To obtain insight into the factors controlling $\mathrm{P}$ regeneration and burial during formation of the S1 and Pliocene sapropels, the sedimentary $\mathrm{P}$ cycle for cores BC19, and 969E was reconstructed using the approach outlined by Slomp et al. (2002) and briefly described here. Cores MD90917 and SL60 were omitted because of the possible importance of oxic decomposition at these sites (Casford et al., 2003). Deposition rates of the three potential sources of $\mathrm{P}_{\text {reac }}$ to the sediment, (1) $\mathrm{P}_{\text {org }}$, (2) Fe-bound $\mathrm{P}$ and (3) biogenic $\mathrm{P}$, were estimated by using burial fluxes of $\mathrm{C}$ or $\mathrm{P}$ as proxies. Sediment-water exchange rates of $\mathrm{HPO}_{4}^{2-}$ were then calculated as the difference between the depositional and burial flux (Table 4) of $\mathrm{P}_{\text {reac }}$. The depositional flux of $\mathrm{P}_{\text {org }}$ was estimated from the average burial flux of $\mathrm{C}_{\text {org }}$ (Tables 3 and 4 ), the $\mathrm{BE}$ of $\mathrm{C}$ in the sapropel, and the $\mathrm{C} / \mathrm{P}$ ratio of the deposited organic matter:

$\mathrm{P}_{\text {org }}$ deposition flux $=\frac{\mathrm{C}_{\text {org }} \text { burial flux }}{\mathrm{BE}_{\mathrm{C}_{\text {org }}}} \times \frac{\mathrm{P}_{\text {org }}}{\mathrm{C}_{\text {org }}}$

The Redfield ratio (106) was used as an approximation of the original $\mathrm{C} / \mathrm{P}$ ratio of the deposited organic matter. Assuming all organic matter remineralization took place by sulfate reduction, the burial efficiencies of $\mathrm{C}_{\text {org }}$ in the sapropels can be calculated from the integrated amounts of $\mathrm{C}_{\mathrm{org}}$ and $\mathrm{S}$ in the sediments, using appropriate values for sulfide reoxidation (Passier et al., 1999c):

$\mathrm{BE}_{\mathrm{C}_{\text {org }}}=\frac{\mathrm{C}_{\text {int }}}{2 \times\left(\frac{100}{100-b}\right) \times \mathrm{S}_{\text {int }}+\mathrm{C}_{\text {int }}} \times 100 \%$

where $b$ is the percentage of total produced sulfide that was reoxidized, the factor 2 accounts for the fact that $2 \mathrm{~mol}$ of $\mathrm{C}$ are oxidized per mole of $\mathrm{S}$ produced, and $\mathrm{C}_{\text {int }}$ and $\mathrm{S}_{\text {int }}$ (both in $\mathrm{mol} \mathrm{m}{ }^{-2}$ ) are the depth integrated amounts of $\mathrm{C}_{\text {org }}$ and reduced $\mathrm{S}$ in and below the sapropel, respectively. Here,

Fig. 3. Solid phase profiles of total $\mathrm{P}$, Fe-bound $\mathrm{P}, \mathrm{P}_{\text {org }}$, authigenic+biogenic $\mathrm{P}$, and detrital $\mathrm{P}$ (closed symbols; all in $\mu \mathrm{mol} / \mathrm{g}$ ) for cores BC19, SL60, MD90-917 and 969E. Open symbols in the plots for core 969E are corrected Fe-bound P and authigenic+biogenic $\mathrm{P}$ contents (see text). 
Table 2

Sediment $\mathrm{P}$ forms in selected samples from cores BC19, SL60, MD90-917 and 969E

\begin{tabular}{|c|c|c|c|c|c|c|c|c|}
\hline Site & $\begin{array}{l}\text { Depth } \\
(\mathrm{cm})\end{array}$ & $\begin{array}{l}\text { Total P } \\
\mu \mathrm{mol} / \mathrm{g}\end{array}$ & $\begin{array}{l}\text { Fe-P } \\
\mu \mathrm{mol} / \mathrm{g}\end{array}$ & $\begin{array}{l}\text { Org. P } \\
\mu \mathrm{mol} / \mathrm{g}\end{array}$ & $\begin{array}{l}\text { Auth.+Bio. P } \\
\mu \mathrm{mol} / \mathrm{g}\end{array}$ & $\begin{array}{l}\text { Detr. P } \\
\mu \mathrm{mol} / \mathrm{g}\end{array}$ & $\begin{array}{l}\mathrm{C}_{\text {org }} / \mathrm{P}_{\text {org }} \\
\mathrm{mol} / \mathrm{mol}\end{array}$ & $\begin{array}{c}\mathrm{C}_{\text {org }} / \mathrm{P}_{\text {reac }} \\
\mathrm{mol} / \mathrm{mol}\end{array}$ \\
\hline \multirow[t]{16}{*}{ BC19 } & 0.4 & 10.9 & 4.88 & 3.01 & 3.23 & 1.54 & 135 & 36 \\
\hline & 3.9 & 11.3 & 4.63 & 2.50 & 3.53 & 1.60 & 76 & 18 \\
\hline & 7.9 & 12.0 & 4.89 & 2.68 & 3.34 & 1.89 & 64 & 16 \\
\hline & 11.9 & 11.4 & 4.52 & 2.35 & 3.84 & 1.55 & 57 & 12 \\
\hline & 15.9 & 14.8 & 4.52 & 3.65 & 5.62 & 1.53 & 47 & 13 \\
\hline & 19.9 & 19.0 & 8.89 & 2.98 & 5.47 & 1.57 & 77 & 13 \\
\hline & 21.4 & 21.3 & 10.99 & 3.69 & 5.61 & 1.75 & 86 & 16 \\
\hline & 21.9 & 33.1 & 13.64 & nd & 8.30 & 1.96 & nd & nd \\
\hline & 22.1 & 28.0 & 15.27 & 3.98 & 7.80 & 1.25 & 173 & 25 \\
\hline & 22.9 & 25.8 & 8.08 & nd & 7.70 & 1.17 & nd & nd \\
\hline & 23.4 & 28.1 & 2.06 & 4.32 & 15.23 & 1.21 & 711 & 142 \\
\hline & 24.4 & 13.8 & 1.34 & 4.51 & 5.74 & 1.32 & 656 & 255 \\
\hline & 25.4 & 17.4 & 2.05 & 4.68 & 8.91 & 1.38 & 687 & 206 \\
\hline & 26.4 & 19.5 & 2.05 & 5.13 & 10.40 & 1.68 & 494 & 144 \\
\hline & 27.9 & 14.7 & 1.53 & 4.94 & 5.81 & 1.79 & 262 & 106 \\
\hline & 30.9 & 13.5 & 2.92 & 3.49 & 5.02 & 1.98 & 86 & 26 \\
\hline \multirow[t]{28}{*}{ SL60 } & 0.5 & 12.4 & 2.97 & 4.74 & 2.75 & 2.40 & 50 & 23 \\
\hline & 10.5 & 12.7 & 3.36 & 3.93 & 3.42 & 2.15 & 44 & 16 \\
\hline & 20.5 & 12.6 & 2.74 & 3.85 & 3.19 & 2.36 & 40 & 16 \\
\hline & 30.5 & 12.1 & 2.54 & 4.16 & 3.00 & 2.58 & 33 & 14 \\
\hline & 40.5 & 11.2 & 0.89 & 5.67 & 2.90 & 1.30 & 9 & 5 \\
\hline & 50.5 & 11.9 & 0.30 & 5.56 & 2.44 & 2.97 & 6 & 4 \\
\hline & 59.5 & 12.8 & 3.68 & 3.23 & 4.58 & 1.99 & 32 & 9 \\
\hline & 60.5 & 14.0 & 4.89 & 3.05 & 4.44 & 2.16 & 48 & 12 \\
\hline & 62.5 & 12.7 & 3.11 & 3.71 & 4.44 & 2.14 & 50 & 16 \\
\hline & 70.5 & 13.6 & 5.34 & 2.99 & 4.22 & 2.46 & 57 & 14 \\
\hline & 73.5 & 15.2 & 5.77 & 3.85 & 4.37 & 2.67 & 45 & 12 \\
\hline & 75.5 & 13.3 & 3.85 & 3.06 & 4.60 & 2.42 & 75 & 20 \\
\hline & 78.5 & 14.2 & 4.04 & 3.70 & 4.69 & 2.27 & 364 & 108 \\
\hline & 82.5 & 14.1 & 3.69 & 2.89 & 5.90 & 2.03 & 470 & 109 \\
\hline & 84.5 & 13.6 & 3.41 & 3.13 & 4.59 & 1.96 & 450 & 127 \\
\hline & 85.5 & 13.4 & 3.00 & 4.05 & 3.92 & 1.86 & 236 & 87 \\
\hline & 88.5 & 13.3 & 3.27 & 2.67 & 5.17 & 2.14 & 262 & 63 \\
\hline & 90.5 & 13.1 & 3.36 & 3.06 & 4.08 & 2.09 & 239 & 69 \\
\hline & 91.5 & 15.9 & 3.43 & 4.70 & 5.04 & 1.97 & 225 & 80 \\
\hline & 92.5 & 14.8 & 3.49 & 1.97 & 5.23 & 1.93 & 658 & 121 \\
\hline & 94.5 & 13.5 & 3.91 & 3.49 & 4.39 & 1.98 & 408 & 121 \\
\hline & 96.5 & 16.0 & 3.58 & 3.75 & 6.01 & 1.96 & 475 & 134 \\
\hline & 98.5 & 15.5 & 4.67 & 4.03 & 9.64 & 1.72 & 465 & 102 \\
\hline & 100.5 & 12.3 & 4.16 & 1.87 & 4.81 & 1.44 & 1114 & 193 \\
\hline & 102.5 & 14.7 & 3.95 & 2.83 & 5.34 & 1.55 & 610 & 142 \\
\hline & 103.5 & 11.9 & 4.07 & 2.66 & 3.39 & 1.55 & 427 & 112 \\
\hline & 105.5 & 12.4 & 4.23 & 2.65 & 3.50 & 2.07 & 146 & 37 \\
\hline & 110.5 & 12.8 & 3.01 & 2.94 & 3.80 & 2.32 & 61 & 18 \\
\hline \multirow[t]{8}{*}{ MD90-917 } & 203.5 & 13.8 & 5.34 & 2.15 & 4.82 & 1.59 & 164 & 29 \\
\hline & 213.5 & 13.4 & 4.76 & 1.95 & 4.96 & 1.35 & 179 & 29 \\
\hline & 222.5 & 14.5 & 4.69 & 2.69 & 4.83 & 1.49 & 175 & 36 \\
\hline & 225.5 & 16.2 & 6.63 & 2.42 & 5.38 & 1.90 & 244 & 41 \\
\hline & 227.5 & 18.3 & 6.14 & 2.95 & 7.67 & 1.88 & 210 & 38 \\
\hline & 228.5 & 16.3 & 6.15 & 2.65 & 5.70 & 1.87 & 268 & 49 \\
\hline & 230.5 & 15.0 & 6.82 & 3.45 & 5.49 & 1.78 & 208 & 54 \\
\hline & 232.5 & 14.6 & 6.87 & 3.43 & 4.83 & 1.70 & 244 & 65 \\
\hline
\end{tabular}


Table 2 (Continued).

\begin{tabular}{|c|c|c|c|c|c|c|c|c|}
\hline Site & $\begin{array}{l}\text { Depth } \\
\text { (cm) }\end{array}$ & $\begin{array}{l}\text { Total P } \\
\mu \mathrm{mol} / \mathrm{g}\end{array}$ & $\begin{array}{l}\mathrm{Fe}-\mathrm{P} \\
\mu \mathrm{mol} / \mathrm{g}\end{array}$ & $\begin{array}{l}\text { Org. P } \\
\mu \mathrm{mol} / \mathrm{g}\end{array}$ & $\begin{array}{l}\text { Auth.+Bio. P } \\
\mu \mathrm{mol} / \mathrm{g}\end{array}$ & $\begin{array}{l}\text { Detr. P } \\
\mu \mathrm{mol} / \mathrm{g}\end{array}$ & $\begin{array}{l}\mathrm{C}_{\text {org }} / \mathrm{P}_{\text {org }} \\
\mathrm{mol} / \mathrm{mol}\end{array}$ & $\begin{array}{l}\mathrm{C}_{\text {org }} / \mathrm{P}_{\text {reac }} \\
\mathrm{mol} / \mathrm{mol}\end{array}$ \\
\hline \multirow{25}{*}{ ODP 969E } & 235.5 & 14.0 & 6.32 & 3.43 & 4.61 & 1.33 & 239 & 65 \\
\hline & 238.5 & 13.0 & 6.40 & 2.54 & 4.59 & 1.34 & 245 & 53 \\
\hline & 241.5 & 13.8 & 5.60 & 2.89 & 4.71 & 2.25 & 183 & 46 \\
\hline & 245.5 & 14.6 & 5.68 & 3.89 & 5.50 & 1.63 & 188 & 56 \\
\hline & 248.5 & 14.9 & 5.59 & 3.96 & 5.61 & 1.57 & 244 & 73 \\
\hline & 250.5 & 14.4 & 6.69 & 3.55 & 5.11 & 1.78 & 260 & 73 \\
\hline & 253.5 & 14.6 & 6.88 & 3.28 & 4.43 & 2.44 & 296 & 80 \\
\hline & 254.5 & 14.7 & 3.75 & 2.81 & 4.97 & 2.11 & 301 & 67 \\
\hline & 255.5 & 13.9 & 3.94 & 2.81 & 5.07 & 2.00 & 144 & 34 \\
\hline & 262.5 & 15.1 & 3.92 & 4.36 & 5.51 & 2.36 & 94 & 32 \\
\hline & 268.5 & 15.8 & 4.83 & 2.67 & 6.25 & 2.49 & 133 & 27 \\
\hline & 21.5 & 13.6 & 0.73 & 2.14 & 7.92 & 2.14 & 38 & 7 \\
\hline & 25.5 & 15.7 & 0.82 & 3.86 & 8.33 & 2.17 & 173 & 50 \\
\hline & 26.5 & 18.0 & 0.57 & 2.67 & 11.17 & 2.00 & 1142 & 248 \\
\hline & 27.5 & 19.2 & 1.00 & 4.98 & 11.80 & 1.79 & 1019 & 339 \\
\hline & 29.5 & 18.2 & 1.46 & 4.55 & 10.45 & 1.67 & 2106 & 634 \\
\hline & 31.5 & 22.5 & 8.28 (1.72) & 6.66 & $5.29(11.85)$ & 0.67 & 3332 & 931 \\
\hline & 32.5 & 19.7 & $6.30(1.85)$ & 5.14 & $4.83(9.28)$ & 0.73 & 4432 & 1103 \\
\hline & 33.5 & 24.9 & 5.33 (1.98) & 8.88 & $6.76(10.10)$ & 1.28 & 2493 & 962 \\
\hline & 35.5 & 33.0 & $9.32(2.24)$ & 4.87 & $13.13(20.21)$ & 1.65 & 4435 & 913 \\
\hline & 37.5 & 18.0 & 2.50 & 3.97 & 11.55 & 1.26 & 4171 & 1273 \\
\hline & 39.5 & 12.4 & 2.76 & 2.95 & 7.81 & 0.83 & 870 & 284 \\
\hline & 40.5 & 11.6 & 2.16 & 2.81 & 6.55 & 0.97 & 38 & 11 \\
\hline & 45.5 & 12.9 & 2.34 & 2.45 & 7.11 & 1.72 & 30 & 8 \\
\hline & 49.5 & 13.3 & 2.02 & 1.59 & 8.37 & 1.94 & 44 & 9 \\
\hline
\end{tabular}

nd = no data. Numbers between brackets for core 969E are corrected Fe-P and auth+bio P values (see text). Data in bold are for intact sapropels. The interruption in sapropel S1 in cores SL60 and MD90-917 is indicated with italics.

Table 3

Average burial fluxes of sediment, $\mathrm{C}_{\text {org }}, \mathrm{P}_{\text {org }}$, Fe-bound $\mathrm{P}$, authigenic+biogenic $\mathrm{P}$ and total $\mathrm{P}$ and the ratios of the burial fluxes of $\mathrm{C}_{\mathrm{org}}$ and several $\mathrm{P}$ forms for cores BC19, SL60, MD90-917 and 969E during sapropel formation and for core BC19 after sapropel formation

\begin{tabular}{|c|c|c|c|c|c|}
\hline \multirow[t]{2}{*}{ Burial flux } & \multicolumn{2}{|l|}{$\begin{array}{l}\text { BC19 } \\
(2750 \mathrm{~m})\end{array}$} & \multirow{2}{*}{$\begin{array}{l}\text { SL60 } \\
(1522 \mathrm{~m}) \\
\text { during S1 }\end{array}$} & \multirow{2}{*}{$\begin{array}{l}\text { MD90-917 } \\
(1010 \mathrm{~m}) \\
\text { during S1 }\end{array}$} & \multirow{2}{*}{$\begin{array}{l}969 \mathrm{E} \\
(2201 \mathrm{~m}) \\
\text { during Pliocene (i-282c) }\end{array}$} \\
\hline & after $\mathrm{S} 1$ & during $\mathrm{S} 1$ & & & \\
\hline Bulk sediment $\left(\mathrm{cm} \mathrm{kyr}^{-1}\right)$ & 2.9 & 2.9 & 8.4 & $\sim 10$ & 3.0 \\
\hline Dry sediment $\left(\mathrm{g} \mathrm{cm}^{-2} \mathrm{yr}^{-1}\right)$ & $2.7 \times 10^{-3}$ & $1.3 \times 10^{-3}$ & $6.7 \times 10^{-3}$ & $8.0 \times 10^{-3}$ & $3.9 \times 10^{-3}$ \\
\hline$-\mathrm{C}_{\mathrm{org}}\left(\mathrm{mmol} \mathrm{m}{ }^{-2} \mathrm{yr}^{-1}\right)$ & 6 & 33 & 82 & 56 & 556 \\
\hline$-\mathrm{P}_{\mathrm{org}}\left(\mu \mathrm{mol} \mathrm{m} \mathrm{m}^{-2} \mathrm{yr}^{-1}\right)$ & $70(23 \%)$ & $62(24 \%)$ & $209(23 \%)$ & $248(22 \%)$ & $195(24 \%)$ \\
\hline$-\mathrm{P}_{\mathrm{Fe}}\left(\mu \mathrm{mol} \mathrm{m} \mathrm{m}^{-2} \mathrm{yr}^{-1}\right)$ & $126(41 \%)$ & $24(9 \%)$ & $244(27 \%)$ & $386(34 \%)$ & $73(9 \%)$ \\
\hline$-\mathrm{P}_{\text {auth.+bio. }}\left(\mu \mathrm{mol} \mathrm{m}{ }^{-2} \mathrm{yr}^{-1}\right)$ & $94(31 \%)$ & $119(46 \%)$ & $339(37 \%)$ & $404(35 \%)$ & $467(57 \%)$ \\
\hline$-\mathrm{P}_{\text {total }}\left(\mu \mathrm{mol} \mathrm{m}{ }^{-2} \mathrm{yr}^{-1}\right)$ & 307 & 257 & 915 & 1150 & 822 \\
\hline $\mathrm{C}_{\text {org }} / \mathrm{P}_{\text {org }}$ & 86 & 528 & 393 & 228 & 2858 \\
\hline $\mathrm{C}_{\text {org }} / \mathrm{P}_{\text {reac }}$ & 21 & 161 & 104 & 54 & 758 \\
\hline
\end{tabular}

Values between brackets are percentages of the total P flux. The fluxes were calculated from the integrated amounts of each component in the intact sapropel (flux during sapropel formation) and from concentrations in the upper $\sim 12 \mathrm{~cm}$ of the sediment (flux after S1, only for core $\mathrm{BC} 19$ ) using the dry bulk density and the sedimentation rate for each location. $\mathrm{P}_{\mathrm{Fe}}=\mathrm{Fe}-$ bound $\mathrm{P}$, $\mathrm{P}_{\text {auth.+bio. }}=$ authigenic and biogenic $\mathrm{P}, \mathrm{P}_{\text {total }}=$ total $\mathrm{P}$. The corrected $\mathrm{P}_{\mathrm{Fe}}$ and $\mathrm{P}_{\text {auth.+bio }}$ data (see text) for core $969 \mathrm{E}$ were used.

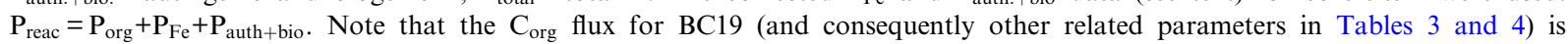
slightly lower than the $40 \mathrm{mmol} \mathrm{m}{ }^{-2} \mathrm{yr}^{-1}$ reported by Slomp et al. (2002). The value given here is a more accurate estimate. 


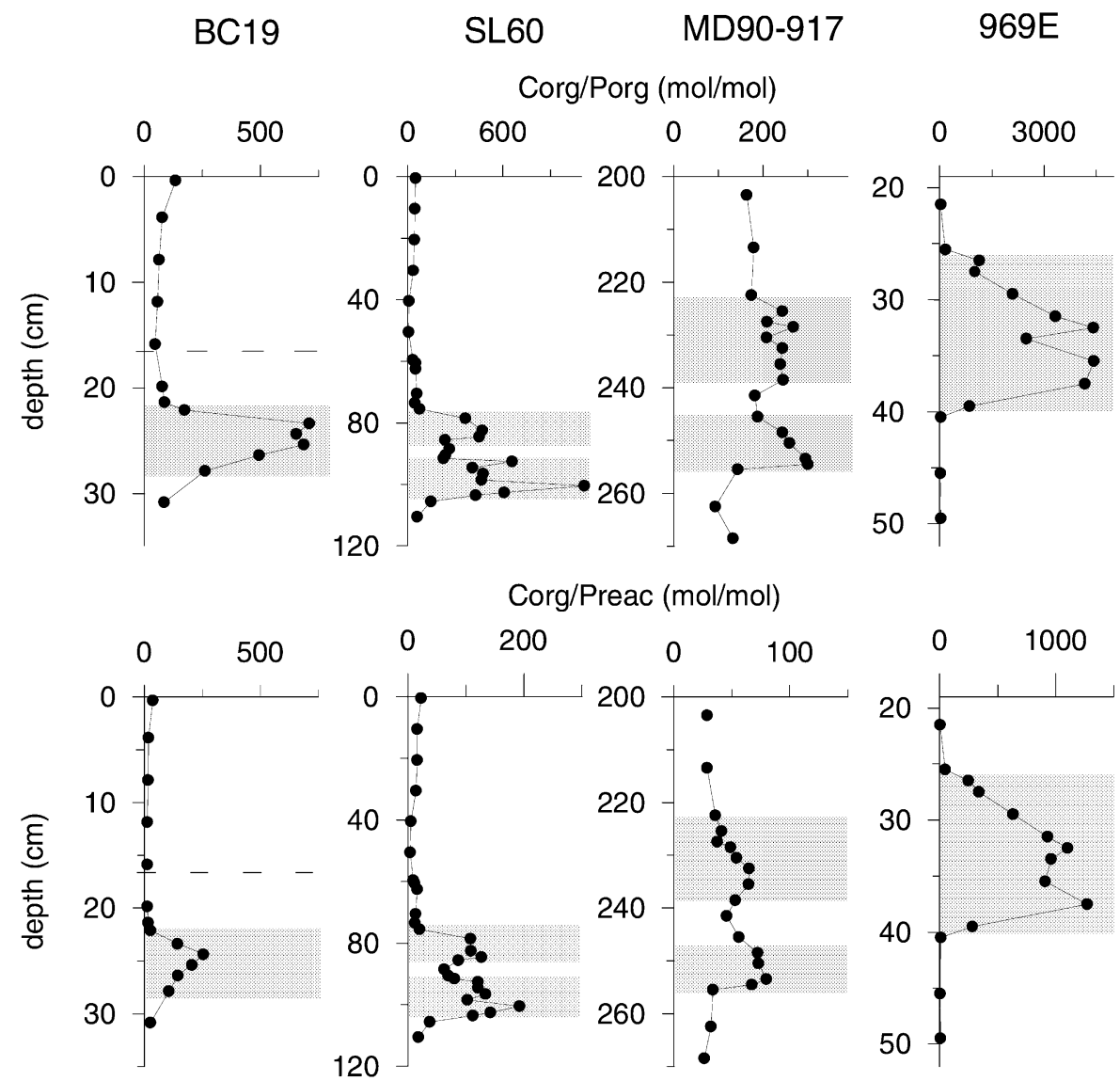

Fig. 4. $\mathrm{C}_{\text {org }} / \mathrm{P}_{\text {org }}$ and $\mathrm{C}_{\text {org }} / \mathrm{P}_{\text {reac }}(\mathrm{mol} / \mathrm{mol})$ versus depth in the sediment of cores BC19, SL60, MD90-917 and 969E.

we assumed either a sulfide reoxidation percentage of $80 \%$, which is a maximum value for sapropel S1 (Passier et al., 1999c), or no sulfide reoxidation. Due to the more abundant presence of oxygen, sulfide reoxidation probably was more important (i.e. closer to $80 \%$ ) during sapropel S1 formation than during formation of the Pliocene sapropel (Passier et al., 1999c). Calculated $\mathrm{C}_{\text {org }}$ burial efficiencies for $\mathrm{BC} 19$ and $969 \mathrm{E}$ are 21 to $44 \%$ (S-ox 80\%) and 57 to $80 \%$ (S-ox 0\%; Table $4)$, respectively. These values all fall within the range of burial efficiencies $(\sim 10-80 \%)$ reported by Canfield (1989) for euxinic environments.

The depositional flux of Fe-bound $\mathrm{P}$ will have depended on the oxygen concentration in the water column. As a rough approximation, it is assumed here that this flux amounted to $\sim 1$
(969E) or $\sim 3$ (BC19) times the burial fluxes of $\mathrm{Fe}$-bound $\mathrm{P}$. These estimates are of the same order of magnitude as present-day fluxes of $\mathrm{Fe}$ bound $\mathrm{P}$ in the surface sediment (Table 3 ). The depositional flux of biogenic $\mathrm{P}$ was calculated from the burial flux of authigenic and biogenic $\mathrm{P}$, assuming a background flux of $\mathrm{P}_{\text {auth }}$ as calculated for core $\mathrm{BC} 19$ from the $\mathrm{P}_{\mathrm{auth}}$ profile $(\sim 31$ $\mu \mathrm{mol} \mathrm{m}{ }^{-2} \mathrm{yr}^{-1}$; Slomp et al., 2002), and assuming a BE for biogenic $\mathrm{P}$ of $10 \%$ (Schenau and De Lange, 2000).

Burial fluxes of total $\mathrm{P}$ range from $\sim 260$ to $1150 \mu \mathrm{mol} \mathrm{m} \mathrm{mr}^{-1}$ (Table 3) and thus are equal to or slightly higher than typical values for open ocean regions $\left(20-750 \mu \mathrm{mol} \mathrm{m}{ }^{-2} \mathrm{yr}^{-1}\right.$; Filippelli, 1997). Calculated maximum rates of $P$ release from the sediment to the water column during 
Table 4

Burial efficiencies (BE) and burial and depositional fluxes of $\mathrm{C}_{\text {org }}, \mathrm{P}_{\text {org }}$, and $\mathrm{P}_{\text {reac }}$ (defined as the sum of organic, Fe-bound, authigenic and biogenic $\mathrm{P}$ ), rates of $\mathrm{C}_{\mathrm{org}}$ decomposition and sediment-water exchange rates of $\mathrm{HPO}_{4}^{2-}$ for cores $\mathrm{BC} 19$ and $969 \mathrm{E}$ during sapropel formation

\begin{tabular}{|c|c|c|c|c|}
\hline & \multicolumn{2}{|c|}{$\begin{array}{c}\text { BC19 (S1) } \\
(2750 \mathrm{~m})\end{array}$} & \multicolumn{2}{|c|}{$\begin{array}{c}\text { 969E (Pliocene) } \\
(2201 \mathrm{~m})\end{array}$} \\
\hline & Sox $-0 \%$ & Sox $-80 \%$ & Sox $-0 \%$ & Sox $-80 \%$ \\
\hline $\mathrm{BE}$ for $\mathrm{C}_{\mathrm{org}}$ & $57 \%$ & $19 \%$ & $80 \%$ & $44 \%$ \\
\hline Burial flux $C_{\text {org }}\left(\mathrm{g} \mathrm{m}^{-2} \mathrm{yr}^{-1}\right)$ & \multicolumn{2}{|c|}{0.4} & \multicolumn{2}{|c|}{6.7} \\
\hline Depositional flux $C_{\text {org }}\left(\mathrm{g} \mathrm{m}^{-2} \mathrm{yr}^{-1}\right)$ & 0.7 & 2.6 & 8.4 & 15.2 \\
\hline $\mathrm{BE}$ for $\mathrm{P}_{\text {org }}$ & $11 \%$ & $4 \%$ & $3 \%$ & $2 \%$ \\
\hline \multicolumn{5}{|l|}{ Depositional flux $\left(\mu \mathrm{mol} \mathrm{m} \mathrm{m}^{-2} \mathrm{yr}^{-1}\right)$ of } \\
\hline$-\mathrm{P}_{\text {org }}$ & \multirow{2}{*}{\multicolumn{2}{|c|}{75}} & \multirow{2}{*}{\multicolumn{2}{|c|}{73}} \\
\hline - Fe-bound P & & & & \\
\hline - Biogenic P & & 878 & & 4061 \\
\hline Depositional flux $\mathrm{P}_{\text {reac }}\left(\mu \mathrm{mol} \mathrm{m} \mathrm{m}^{-2} \mathrm{yr}^{-1}\right)$ & 1500 & 2443 & 10724 & 16090 \\
\hline Burial flux $\mathrm{P}_{\text {reac }}\left(\mu \mathrm{mol} \mathrm{m} \mathrm{m}^{-2} \mathrm{yr}^{-1}\right)$ & \multicolumn{2}{|c|}{205} & \multicolumn{2}{|c|}{734} \\
\hline Sediment-water exchange flux of $\mathrm{HPO}_{4}^{2-}\left(\mu \mathrm{mol} \mathrm{m}{ }^{-2} \mathrm{yr}^{-1}\right)$ & 1295 & 2238 & 9990 & 15356 \\
\hline $\mathrm{BE}$ for $\mathrm{P}_{\text {reac }}$ & $14 \%$ & $8 \%$ & $7 \%$ & $5 \%$ \\
\hline
\end{tabular}

Sox- $0 \%$ : no sulfide reoxidation, Sox- $80 \%: 80 \%$ of the sulfide formed is reoxidized.

sapropel formation range from $\sim 1295$ to $\sim 15360 \mu \mathrm{mol} \mathrm{m}{ }^{-2} \mathrm{yr}^{-1}$ (Table 4). These fluxes are significantly higher than present day fluxes in oxic environments with comparably low sedimentation rates (generally $<1000 \mu \mathrm{mol} \mathrm{m} \mathrm{m}^{-2} \mathrm{yr}^{-1}$; Colman and Holland, 2000; Slomp et al., 2002). When compared to values reported for continental margin environments overlain by anoxic bottom waters $\left(\sim 2900-59000 \mu \mathrm{mol} \mathrm{m} \mathrm{m}^{-2} \mathrm{yr}^{-1}\right.$; McManus et al., 1997; Slomp et al., 2002), the fluxes for core $969 \mathrm{E}$ fall within the typical range but those for $\mathrm{BC} 19$ are relatively low. Estimated burial efficiencies of organic and reactive $\mathrm{P}$ range from 2 to $11 \%$ and 5 to $14 \%$, respectively (Table 4). The burial efficiencies of $P_{\text {reac }}$ compare well to the values of 6 and 12\% observed by Ingall and Jahnke (1994) for the anoxic Peru Margin and Santa Monica basin, respectively.

Since the major source of $\mathrm{P}$ to the sediment is $\mathrm{P}_{\text {org }}$ (Table 4; assuming S-ox closer to $80 \%$ than $0 \%$ for $\mathrm{S} 1$ ) and the depositional flux of $\mathrm{P}_{\text {org }}$ is based on the depositional flux of $\mathrm{C}_{\mathrm{org}}$, the reconstructed sediment-water exchange fluxes and burial efficiencies are particularly sensitive to the assumed organic $\mathrm{C} / \mathrm{P}$ ratio. Use of the Redfield $\mathrm{C} / \mathrm{P}$ ratio (106) makes the $\mathrm{P}_{\text {org }}$ deposition fluxes maximum values. Some loss of $\mathrm{P}$ relative to $\mathrm{C}$ will probably have occurred during downward transport through the water column. When using a $\mathrm{C} / \mathrm{P}$ ratio of 228 , which is the average value for the sapropel in core MD90-917, sediment-water exchange rates are a factor $\sim 0.6$ lower and burial efficiencies of $\mathrm{P}_{\text {reac }}$ will increase by a factor of $\sim 1.5$ when S-ox is $80 \%$ at sites $\mathrm{BC} 19$ and 969E. These values are still reasonable compared to those determined for other systems. When we assume that the depositional flux of biogenic $\mathrm{P}$ is zero (with S-ox $80 \%$ for S1) burial efficiencies comparable to those in modern sediments overlain by anoxic bottom waters are only obtained if we assume Redfield $\mathrm{C} / \mathrm{P}$ ratios for the organic matter. Calculated burial efficiencies are not sensitive to possible errors in sedimentation rates, since this equally affects both the estimated depositional and burial rates.

\subsection{Regeneration and burial of $C$ and $P$ from organic matter}

Burial efficiencies of $\mathrm{C}_{\text {org }}$ are expected to increase with sedimentation rate (e.g. Canfield, 1994), with enhanced sulfurization of organic matter (e.g. Van Kaam-Peters et al., 1998; Sinnighe Damsté et al., 1998) and with decreased 
exposure of the organic matter to oxygen (e.g. Hartnett et al., 1998). Assuming 80\% reoxidation for $\mathrm{S} 1$ and less than $80 \%$ for the Pliocene sapropel, estimated burial efficiencies for $\mathrm{C}_{\text {org }}$ (Table 4), indicate that $\mathrm{C}_{\text {org }}$ preservation was higher during Pliocene sapropel formation than during S1 times. A similar conclusion was reached by Passier et al. (1999c) and was suggested to be the result of the much larger uptake of reduced sulfur by organic matter during formation of the Pliocene sapropel in core 969E (Passier et al., 1999b). The more limited exposure of organic matter to oxygen during Pliocene sapropel formation compared to S1 may also play a role.

Burial efficiencies for $\mathrm{P}_{\text {org }}$ are a factor $\sim 5$ to 27 lower than burial efficiencies for $\mathrm{C}_{\text {org }}$ (Table 4). This is in accordance with the elevated $\mathrm{C}_{\text {org }} / \mathrm{P}_{\text {org }}$ ratios in the sapropels (Tables 2 and 3; Fig. 4) and indicates enhanced release of $\mathrm{P}$ from organic matter relative to $\mathrm{C}$ under bottom water dysoxia/ anoxia. When the bottom water was temporarily more oxygenated during the 'interruption' of S1 in cores SL60 and MD90-917, $\mathrm{P}_{\text {org }}$ burial relative to $\mathrm{C}_{\text {org }}$ increased (reflected in decreased $\mathrm{C}_{\text {org }} / \mathrm{P}_{\text {org }}$ ratios; Table 2; Fig. 4). Decreasing $\mathrm{C}_{\text {org }} / \mathrm{P}_{\text {org }}$ ratios with sedimentation rate and water depth (Table 3; Fig. 4) can be attributed to (1) higher oxygen exposure at the shallower sites; (2) faster burial and therefore better preservation of the deposited organic matter at the high sedimentation rate sites (Ingall and Van Cappellen, 1990); (3) a greater input of (residual) organic matter with low $\mathrm{C}_{\text {org }} / \mathrm{P}_{\text {org }}$ ratios at the shallower sites. Increased terrestrial input at the more near coastal sites SL60 and MD90-917 compared to site BC19 would lead to higher (Ruttenberg and Goni, 1997) instead of lower C/P ratios at the former sites and thus can be excluded.

Assuming S-ox is close to $80 \%$ for S1, burial efficiencies for $\mathrm{P}_{\text {org }}$ for core $\mathrm{BC} 19$ and $969 \mathrm{E}$ are surprisingly close at 2-4\% (Table 4 ),. This suggests that the $\sim 5$-fold difference in average $\mathrm{C}_{\text {org }} / \mathrm{P}_{\text {org }}$ ratios for $\mathrm{S} 1$ and the Pliocene sapropel can largely be attributed to an enhanced $\mathrm{BE}$ of $\mathrm{C}_{\text {org }} . \mathrm{P}_{\text {org }}$ burial efficiencies are apparently not affected when water column conditions change from dysoxic to euxinic.

The enhanced regeneration of $\mathrm{P}$ from organic matter under anoxia in these sediments is quantitatively more important than the increased release from Fe-oxides. This particularly holds for the Pliocene sapropel when no Fe-oxides are expected to have survived transport through the euxinic water column (although we assume a small depositional flux in Table 4). For S1, we estimated the relative contribution for core $\mathrm{BC} 19$ as follows. Enhanced release of $\mathrm{P}$ from organic matter was calculated as the difference between the burial flux of $\mathrm{P}_{\text {org }}$ if there were no enhanced $\mathrm{P}$ regeneration (the $\mathrm{C}_{\text {org }}$ burial flux in the sapropel divided by the Redfield $\mathrm{C} / \mathrm{P}$ ratio) and the actual $\mathrm{P}_{\text {org }}$ burial flux. The release of Fe-bound $\mathrm{P}$ was estimated from the difference in the depositional and burial fluxes of Fe-bound P (Tables 3 and 4). Enhanced P-release from organic matter during $\mathrm{S} 1$ was calculated to be $\sim 5$ times more important than release from Fe-oxides.

\subsection{Burial of inorganic $P_{\text {reac }}$}

The enhanced release of $\mathrm{P}$ from organic matter and $\mathrm{Fe}$-oxides in sediments overlain by anoxic bottom waters may be partly counteracted by an increased burial of other $P_{\text {reac }}$ phases, such as authigenic CFA and biogenic apatite. Slomp et al. (2002) showed that authigenic CFA formation did not occur at the BC19 site during S1 formation. Biogenic apatite burial was enhanced during this time, but showed a high spatial variability and only partly compensated the enhanced $\mathrm{P}$ release from organic matter.

Similar to $\mathrm{P}_{\text {org }}, \mathrm{P}_{\text {reac }}$ retention can be expected to increase with increasing sedimentation rate and oxygen exposure. This will either be the result of decreased dissolution of Fe-bound and biogenic $\mathrm{P}$ due to the shorter residence time near the sediment-water interface or due to increased transformation of Fe-bound, organic and biogenic $\mathrm{P}$ to CFA. Sapropel $\mathrm{C}_{\text {org }} / \mathrm{P}_{\text {reac }}$ ratios indeed show a decrease (Tables 2 and 3, Fig. 4) with increasing sedimentation rate and oxygen exposure. At sites SL60 and MD90-917, $\mathrm{P}_{\text {auth+bio }}$ accounts for a major proportion of the burial flux in the sapropel, but - apart from some spikes - there is only a minor increase relative to surrounding layers and the surface sediment. This suggests that a 
major part of the $\mathrm{P}_{\text {auth+bio }}$ flux (and thus the $\mathrm{P}_{\text {reac }}$ flux) may in fact be a 'background' flux of $P_{\text {auth+bio }}$ formed elsewhere. Whether the small enrichments are CFA or biogenic Ca-P can not be deduced from these data. Even if it is all CFA, the small enrichments suggest that only limited transformation has taken place. We conclude that (1) $\mathrm{P}$ forms other than $\mathrm{P}_{\text {org }}$ may be major sources of $\mathrm{P}_{\text {reac }}$ to the sediment at these sites; (2) the dissolution kinetics of these $\mathrm{P}$ forms may play an important role in determining $\mathrm{P}_{\text {reac }}$ burial in sediments.

The average $\mathrm{C}_{\text {org }} / \mathrm{P}_{\text {reac }}$. ratio for the Pliocene sapropel is a factor $\sim 5$ higher than that for the deep-basin S1 sapropel in core BC19 (Table 3). Estimated burial efficiencies for $\mathrm{P}_{\text {reac }}$ in these sapropels are rather similar (Table 4). This suggests that - as with the $\mathrm{C}_{\text {org }} / \mathrm{P}_{\text {org }}$ ratios - the $\sim 5$-fold difference in $\mathrm{C}_{\text {org }} / \mathrm{P}_{\text {reac }}$ ratios between $\mathrm{S} 1$ and the Pliocene sapropel can be attributed to an enhanced burial efficiency of $\mathrm{C}_{\mathrm{org}}$. Apparently, the presence of a euxinic instead of a dysoxic or semieuxinic water column does not significantly affect the burial efficiency of $P_{\text {reac }}$ in sediments. Whether the $\mathrm{P}_{\text {auth }+ \text { bio }}$ enrichment in the Pliocene sapropel is largely authigenic or biogenic cannot be deduced from these data with certainty. That biogenic $\mathrm{P}$ may be important is suggested by the 'corrected' $P_{\text {auth+bio }}$ profile (Fig. 3; Table 2). Even if all of the $\mathrm{P}_{\text {auth+bio }}$ were authigenic (i.e. including the background flux), transformation of $\mathrm{P}_{\text {org }}$ to CFA cannot have significantly counteracted the enhanced regeneration of $\mathrm{P}$. Enhanced release of $\mathrm{P}$ at this site (calculated as described in Section 4.3) will have amounted to $\sim 5050 \mu \mathrm{mol} \mathrm{m} \mathrm{m}^{-2} \mathrm{yr}^{-1}$. This is $\sim 11$ times higher than the total $\mathrm{P}_{\text {auth }+ \text { bio }}$ burial flux $\left(467 \mu \mathrm{mol} \mathrm{m}{ }^{-2} \mathrm{yr}^{-1}\right.$; Table 4).

\section{Conclusions and implications}

The $\mathrm{C}$ and $\mathrm{P}$ geochemistry of sapropels from 4 sites in the eastern Mediterranean Sea indicate enhanced regeneration (i.e. decreased burial) of $\mathrm{P}$ relative to $\mathrm{C}$ during formation of sapropel $\mathrm{S} 1$ and the Pliocene sapropel i-282c. This is the result of (1) enhanced release of $\mathrm{P}$ from organic matter during sapropel formation, (2) limited burial of
Fe-bound $\mathrm{P}$ and (3) only limited increased burial of biogenic $\mathrm{P}$ and CFA. For sapropel S1, retention of both $P_{\text {org }}$ and $P_{\text {reac }}$ relative to $C_{\text {org }}$ was found to increase with increasing sedimentation rate and exposure to oxygen. Inorganic $\mathrm{P}_{\text {reac }}$ may be an important source of $\mathrm{P}$ at two sites. This suggests that the general assumption that $\mathrm{P}_{\text {org }}$ is the primary source of $\mathrm{P}_{\text {reac }}$ to sediments (e.g. Berner et al., 1993; Filippelli, 2001) may not hold in all sedimentary environments. Our results are in line with the major role of sediment accumulation (Filippelli, 1997) and bottom water oxygenation (Ingall and Jahnke, 1994, 1997) for $\mathrm{P}$ burial in marine sediments demonstrated previously.

Whether the water column is dysoxic/semi-euxinic or euxinic does not appear to affect the burial efficiencies of $\mathrm{P}_{\text {org }}$ and $\mathrm{P}_{\text {reac }}$. Enhanced $\mathrm{C}_{\mathrm{org}}$ burial under the euxinic water column explains the extremely high $\mathrm{C}_{\text {org }} / \mathrm{P}_{\text {org }}$ and $\mathrm{C}_{\text {org }} / \mathrm{P}_{\text {reac }}$ ratios in the Pliocene sapropel. As was shown previously for sapropel S1 (Slomp et al., 2002), the enhanced regeneration of $\mathrm{P}$ in combination with circulation changes will have contributed to a significant increase in deep-water concentrations of $\mathrm{HPO}_{4}^{2-}$ during Pliocene sapropel formation. The stronger decoupling of the burial of $\mathrm{C}$ and $\mathrm{P}$ during euxinia (Pliocene) compared to dysoxia/semi-euxinia (S1) will have resulted in a stronger positive feed-back loop between water column anoxia, primary productivity and $\mathrm{C}_{\text {org }}$ burial (Van Cappellen and Ingall, 1994, 1996).

Our results indicate that authigenic apatite formation is quantitatively unimportant during S1 and Pliocene sapropel formation relative to the enhanced release from organic matter. This result is seemingly in contrast with the efficient transformation of $\mathrm{P}_{\text {org }}$ to authigenic $\mathrm{P}$ reported for modern anoxic sediments (e.g. Ruttenberg and Berner, 1993). The unusual combination of very low sedimentation rates and bottom water dysoxia/anoxia during sapropel formation (which does not occur in any present-day sedimentary environment) apparently precludes such a transformation. Calculated paleogradients of pore water $\mathrm{PO}_{4}$ in the surface sediment during sapropel S1 formation $(0.7-1.0 \mu \mathrm{M}$ over a $1-\mathrm{cm}$ depth interval in core $\mathrm{BC} 19)$ suggest that porewater $\mathrm{PO}_{4}$ concen- 
trations may have been too low for CFA formation (Slomp et al., 2002).

If we view sapropels as a modern analog of black shales (e.g. Thomson et al., 1999; Nijenhuis et al., 1999; Erbacher et al., 2001), these results may also have wider implications. In their model calculations for global ocean $\mathrm{C}, \mathrm{P}$ and $\mathrm{O}$ cycling, Van Cappellen and Ingall $(1994,1996)$ assumed that CFA formation and burial increased substantially during ocean anoxia as a result of increased primary production. At steady-state, this fully compensated for the decreased burial of organic and Fe-bound P. If our results for Mediterranean sapropels are extrapolated to times of world-wide ocean anoxia (Ocean Anoxic Events or OAE, e.g. Wignall, 1994; Kuypers, 2001), substantial CFA formation and burial of biogenic Ca-P did not take place in the deep-sea (i.e. in pelagic environments). Increased burial of CFA and biogenic $\mathrm{P}$ may have occurred in the coastal zone, however, upon (periodic) upwelling of P-rich bottom water on to the shelves either during or after an OAE (Cook and Shergold, 1984; Donnelly et al., 1990).

\section{Acknowledgements}

We thank the crew and shipboard parties of the cruises with R.V. Logachev, R.V. Marion Dufresne and Drilling Vessel JOIDES Resolution (Ocean Drilling Program, Leg 160) for their contribution to the sample collection. The cruise with $R V$ Logachev was financially supported by NWO (SMILE/PASS2). H. de Waard, I.A. Nijenhuis, D. Mercone and R. Bansie are thanked for their contribution to the laboratory analyses. We thank K.C. Ruttenberg, E. Ingall, H. Chamley and an anonymous reviewer for valuable comments on the manuscript. This work was supported by the European Union Marine Science and Technology Programme, project 'Sapropels and Palaeoceanography', Contract number MAS3-CT970137. C.P.S. was supported by a fellowship of the Royal Netherlands Academy of Arts and Sciences. This is publication no. 20031102 of the Netherlands Research School of Sedimentary Geology (NSG).

\section{References}

Anderson, L.D., Delaney, M.L., Faul, K.L., 2001. Carbon to phosphorus ratios in sediments: Implications for nutrient cycling. Glob. Biogeochem. Cycles 15, 65-79.

Anderson, L.A., Sarmiento, J.L., 1994. Redfield ratios of remineralization determined by nutrient data analysis. Glob. Biogeochem. Cycles 8, 65-80.

Benitez-Nelson, C.R., 2000. The biogeochemical cycling of phosphorus in marine systems. Earth Sci. Rev. 51, 109-135.

Berner, R.A., Ruttenberg, K.C., Ingall, E.D., Rao, J.-L., 1993. The nature of phosphorus burial in modern marine sediments. In: Wollast, R., Mackenzie, F.T., Chou, L. (Eds.), The Nature of Phosphorus Burial in Modern Marine Sediments. Springer-Verlag, NATO ASI Series. Vol. 14. 521 p.

Bosch, H.-J., Sinnighe Damsté, J.S., de Leeuw, J.W., 1998. Molecular palaeontology of eastern Mediterranean sapropels: Evidence for photic zone euxinia. In: Robertson, A.H.F., Emeis, K.-C., Richter, C. and Camerlenghi, A. (Eds.) Proc. ODP, Sci. Res. 160, pp. 285-295.

Bouloubassi, I., Rullkötter, J., Meyers, P.A., 1999. Origin and transformation of organic matter in Pliocene-Pleistocene Mediterranean sapropels: organic geochemical evidence reviewed. Mar. Geol. 153, 177-197.

Broecker, W.S., 1982. Ocean chemistry during glacial time. Geochim. Cosmochim. Acta 46, 1689-1705.

Bruins, H.J., Van der Plicht, J., 1996. The Exodus enigma. Nature 382, 213-214.

Calvert, S.E., Nielsen, B., Fontugne, M.R., 1992. Evidence from nitrogen isotope ratios for enhanced productivity during formation of eastern Mediterranean sapropels. Nature $359,223-225$.

Canfield, D.E., 1989. Sulfate reduction and oxic respiration in marine sediments: implications for organic carbon preservation in euxinic environments. Deep-Sea Res. 36, 121-138.

Canfield, D.E., 1994. Factors influencing organic carbon preservation in marine sediments. Chem. Geol. 114, 315-329.

Casford, J.S.L., Rohling, E.J., Abu-Zied, R.H., Fontanier, C., Jorissen, F.J., Leng, M.J., Schmiedl, G., Thomson, J., 2003. A dynamic concept for eastern Mediterranean circulation and oxygenation during sapropel formation. Palaeogeogr. Palaeoclimatol. Palaeoecol. 190, 103-119.

Colman, A.S., Holland, H.D., 2000. The global diagenetic flux of phosphorus from marine sediments to the oceans: Redox sensitivity and the control of atmospheric oxygen levels. Marine Authigenesis: From global to microbial. SEPM Spec. Publ. 66, 53-75.

Cook, P.J., Shergold, J.H., 1984. Phosphorus, phosphorites and skeletal evolution at the Precambrian-Cambrian boundary. Nature 308, 231-236.

Cotner, J.B., Ammerman, J.W., Peele, E.R., Bentzen, E., 1997. Phosphorus-limited bacterioplankton growth in the Sargasso Sea. Aquat. Microb. Ecol. 13, 141-149.

Delaney, M.L., 1998. Phosphorus accumulation in marine sediments and the oceanic phosphorus cycle. Glob. Biogeochem. Cycles 12, 563-572.

De Lange, G.J., Van Os, B., Pruysers, P.A., Middelburg, J.J., 
Castradori, D., Van Santvoort, P., Müller, P.J., Eggenkamp, H., Prahl, F.G., 1994. Possible early diagenetic alteration of palaeo proxies. In: Zahn, R. et al. (Eds.), Carbon Cycling in the Glacial Ocean: Constraints on the Ocean's Role in Global Change. NATO ASI Series Vol. 117. Springer-Verlag, pp. 225-258.

De Rijk, S., Hayes, A., Rohling, E.J., 1999. Eastern Mediterranean sapropel S1 interruption: an expression of the onset of climatic deterioration around 7 ka BP. Mar. Geol. 153, 337-343.

Donnelly, T.H., Shergold, J.H., Southgate, P.N., Barnes, C.J., 1990. Events leading to global phosphogenesis around the Proterozoic/Cambrian boundary. In: Notholt, A.J.G., Jarvis, I. (Eds.) Phosphorite Research and Development. Geol. Soc. Spec. Publ. 52, pp. 273-287.

Eijsink, L.M., Krom, M.D., De Lange, G.J., 1997. The use of sequential extraction techniques for sedimentary phosphorus in eastern Mediterranean sediments. Mar. Geol. 139, 147155 .

Einsele, W., 1936. Über die Beziehungen des Eisenkreislaufs zum Phosphatkreislauf im eutrophen See. Arch. Hydrobiol. 29, 664-686.

Emeis, K.-C., Robertson, A.H.F., Richter, C. et al., 1996. Proc. ODP Init. Rep. 160, 972 pp.

Erbacher, J., Huber, B.T., Norris, R.D., Markey, M., 2001. Increased thermohaline stratification as a possible cause for an ocean anoxic event in the Cretaeceous period. Nature 409, 325-327.

Filippelli, G.M., 1997. Controls on phosphorus concentration and accumulation in oceanic sediments. Mar. Geol. 139, 231-240.

Filippelli, G.M., 2001. Carbon and phosphorus cycling in anoxic sediments of the Saanich Inlet, British Columbia. Mar. Geol. 174, 307-321.

Filippelli, G.M., Sierro, F.J., Flores, J.A., Vázquez, A., Utrilla, R., Pérez-Folgado, M., Latimer, J.C., 2003. A sedimentnutrient-oxygen feedback responsible for productivity variations in Late Miocene sapropel sequences of the western Mediterranean. Palaeogeogr. Palaeoclimatol. Palaeoecol. 190, 335-348.

Föllmi, K.B., 1996. The phosphorus cycle, phosphogenesis and marine phosphate-rich deposits. Earth Sci. Rev. 40, 55-124.

Granéli, E., Wallstrom, K., Larrson, U., Graneli, W., Elmgren, R., 1990. Nutrient limitation of primary production in the Baltic Sea. Ambios 19, 142-151.

Hartnett, H.E., Keil, R.G., Hedges, J.I., Devol, A.H., 1998. Influence of oxygen exposure time on organic carbon preservation in continental margin sediments. Nature 391, 572574.

Holland, H.D., 1978. The Chemistry of the Atmosphere and the Oceans. Wiley, New York.

Ingall, E.D., Van Cappellen, P., 1990. Relation between sedimentation rate and burial of organic phosphorus and organic carbon in marine sediments. Geochim. Cosmochim. Acta 54, 373-386.

Ingall, E.D., Jahnke, R.A., 1994. Evidence for enhanced phosphorus regeneration from marine sediments overlain by oxy- gen depleted waters. Geochim. Cosmochim. Acta 58, 25712575.

Ingall, E.D., Jahnke, R.A., 1997. Influence of water-column anoxia on the elemental fractionation of carbon and phosphorus during sediment diagenesis. Mar. Geol. 139, 219229.

Ingall, E.D., Bustin, R.M., Van Cappellen, P., 1993. Influence of water column anoxia on the burial and preservation of carbon and phosphorus in marine shales. Geochim. Cosmochim. Acta 57, 303-316.

Karl, D.M., Letelier, R., Tupas, L., Dore, J., Christian, J., Hebel, D., 1997. The role of nitrogen fixation in biogeochemical cycling in the subtropical North Pacific Ocean. Nature 388, 533-538.

Krom, M.D., Kress, N., Benner, S., Gordon, L.I., 1991. Phosphorus limitation of primary productivity in the eastern Mediterranean Sea. Limnol. Oceanogr. 36, 424-432.

Kuypers, M.M.M., 2001. Mechanisms and biogeochemical implications of the mid-Cretaeceous global organic carbon burial events. Geologica Ultraiectina 209. PhD-Thesis. Utrecht University, $135 \mathrm{pp}$.

Langereis, C.G., Dekkers, M.J., De Lange, G.J., Paterne, M., Van Santvoort, P.J.M., 1997. Magenetostratigraphy and astonomical calibration of the last $1.1 \mathrm{Myr}$ from an eastern Mediterranean piston core and dating of short events in the Brunhes. Geophys. J. Int. 129, 75-94.

Lourens, L.J., Hilgen, F.J., Zachariasse, W.J., van Hoof, A.A.M., Antonarakou, A., Vergnaud-Grazzini, C., 1996. Correction to 'Evaluation of the Pliocene to early Pleistocene astronomical time scale'. Paleoceanography 12, 527.

Mach, D.L., Ramirez, A., Holland, H.D., 1987. Organic phosphorus and carbon in marine sediments. Am. J. Sci. 278, 429-441.

McManus, J., Berelson, W.M., Coale, K.H., Johnson, K.S., Kilgore, T.E., 1997. Phosphorus regeneration in continental margin sediments. Geochim. Cosmochim. Acta 61, 28912907.

Mercone, D., Thomson, J., Croudace, I.W., Siani, G., Paterne, M., Troelstra, S., 2000. Duration of S1, the most recent sapropel in the eastern Mediterranean Sea, as indicated by accelerator mass spectrometry radiocarbon and geochemical evidence. Paleoceanography $15,336-347$.

Mercone, D., Thomson, J., Abu-Zied, R.H., Croudace, I.W., Rohling, E.J., 2001. High-resolution geochemical and micropaleontological profiling of the most recent eastern Mediterranean sapropel. Mar. Geol. 177, 25-44.

Mortimer, C.H., 1941. The exchange of dissolved substances between mud and water in lakes. Int. J. Ecol. 30, 280329.

Murat, A., Got, H., 2000. Organic carbon variations of the eastern Mediterranean Holocene sapropel: a key for understanding formation processes. Palaeogeogr. Palaeoclimatol. Palaeoecol. 158, 241-257.

Nijenhuis, I.A., Bosch, H.J., Sinnighe Damsté, J.S., Brumsack, H.-J., De Lange, G.J., 1999. Organic matter and trace element rich sapropels and black shales: a geochemical comparison. Earth Planet. Sci. Lett. 169, 277-290. 
Nijenhuis, I.A., De Lange, G.J., 2000. Geochemical constraints on Pliocene sapropel formation in the eastern Mediterranean. Mar. Geol. 163, 41-63.

Passier, H.F., De Lange, G.J., 1998. Sedimentary sulfur and iron chemistry in relation to the formation of eastern Mediterranean sapropels. Proc. ODP Sci. Res. 160, 249-259.

Passier, H.F., Bosch, H.-J., Nijenhuis, I.A., Lourens, L.J., Böttcher, M.E., Leenders, A., Sinnighe Damsté, J.S., De Lange, G.J., de Leeuw, J.W., 1999a. Sulphidic Mediterranean surface waters during Pliocene sapropel formation. Nature 397, 146-149.

Passier, H.F., Böttcher, M.E., De Lange, G.J., 1999b. Sulphur enrichment in organic matter of eastern Mediterranean sapropels: A study of sulphur isotope partitioning. Aq. Geochem. 5, 99-118.

Passier, H.F., Middelburg, J.J., De Lange, G.J., Böttcher, M.E., 1999c. Modes of sapropel formation in the eastern Mediterranean: some constraints based on pyrite properties. Mar. Geol. 153, 199-219.

Redfield, A.C., Ketchum, B.H., Richards, F.A., 1963. The influence of organisms on the composition of seawater. In: Hill, M.N. (Ed.), The Sea. Interscience, New York, pp. 2677.

Rohling, E.J., 1994. Review and new aspects concerning the formation of eastern Mediterranean sapropels. Mar. Geol. $122,1-28$

Rutten, A., 2002. Fluxes, diagenesis and preservation of recent and Holocene sediments in the eatstern Mediterranean. PhD-Thesis. Faculty of Earth Sciences, Utrecht University, Geologica Ultraiectina no. 202. 173p.

Ruttenberg, K.C., 1992. Development of a sequential extraction method for different forms of phosphorus in marine sediments. Limnol. Oceanogr. 37, 1460-1482.

Ruttenberg, K.C., 1993. Reassessment of the oceanic residence time of phosphorus. Chem. Geol. 107, 405-409.

Ruttenberg, K.C., Berner, R.A., 1993. Authigenic apatite formation and burial in sediments from non-upwelling, continental margin environments. Geochim. Cosmochim. Acta 57, 991-1007.

Ruttenberg, K.C., Goni, M.A., 1997. Phosphorus distribution, $\mathrm{C}: \mathrm{N}: \mathrm{P}$ ratios, and $\delta^{13} \mathrm{C}_{\mathrm{oc}}$ in arctic, temperate, and tropical coastal sediments: tools for characterizing bulk sedimentary organic matter. Mar. Geol. 139, 123-145.

Schenau, S.J., De Lange, G.J., 2000. A novel chemical method to quantify fish debris in marine sediments. Limnol. Oceanogr. 45, 963-971.

Schenau, S.J., De Lange, G.J., 2001. Phosphorus regeneration versus burial in sediments of the Arabian Sea. Mar. Chem. $75,201-217$.

Schenau, S.J., Slomp, C.P., De Lange, G.J., 2000. Phosphogenesis and active phosphorite formation in sediments from the Arabian Sea oxygen minimum zone. Mar. Geol. 169, $1-20$.

Sinnighe Damsté, J.S., Kok, M.D., Koster, J., Schouten, S., 1998. Sulfurized carbohydrates: an important sedimentary sink for organic carbon? Earth Planet. Sci. Lett. 164, 7-13. Slomp, C.P., Epping, E.H.G., Helder, W., van Raaphorst, W., 1996a. A key role for iron-bound phosphorus in authigenic apatite formation in North Atlantic continental platform sediment. J. Mar. Res. 54, 1179-1205.

Slomp, C.P., van der Gaast, S.J., van Raaphorst, W., 1996b. Phosphorus binding by poorly crystalline iron oxides in North Sea sediments. Mar. Chem. 52, 55-73.

Slomp, C.P., Malschaert, J.F.P., van Raaphorst, W., 1998. The role of sorption in sediment-water exchange of phosphate in North Sea continental margin sediments. Limnol. Oceanogr. 43, 832-846.

Slomp, C.P., Thomson, J., De Lange, G.J., 2002. Enhanced regeneration of phosphorus during formation of the most recent eastern Mediterranean sapropel S1. Geochim. Cosmochim. Acta 66, 1171-1184.

Sundby, B., Gobeil, C., Silverberg, N., Mucci, A., 1992. The phosphorus cycle in coastal marine sediments. Limnol. Oceanogr. 37, 1129-1145.

Strickland, T.R., Parsons, J.D., 1972. A practical handbook of seawater analysis, 2nd. edn. Bull. Fish. Res. Bd. Can. 167, pp. 1-311.

Thomson, J., Mercone, D., De Lange, G.J., Van Santvoort, P.J.M., 1999. Review of recent advances in the interpretation of eastern Mediterranean sapropel S1 from geochemical evidence. Mar. Geol. 153, 77-89.

Thouveny, N., Moreno, E., Delanghe, D., Candon, L., Lancelot, Y., Shackleton, N.J., 2000. Rock magnetic detection of distal ice-rafted debris: clue for the identification of Heinrich layers on the Portugese margin. Earth Planet. Sci. Lett. $180,61-75$.

Tyrell, T., 1999. The relative influence of nitrogen to phosphorus on oceanic primary production. Nature 400, 525-531.

Van Cappellen, P., Berner, R.A., 1988. A mathematical model for the early diagenesis of phosphorus and fluorine in marine sediments: apatite precipitation. Am. J. Sci. 288, 289333.

Van Cappellen, P., Ingall, E.D., 1994. Benthic phosphorus regeneration, net primary production, and ocean anoxia: A model of the coupled marine biogeochemical cycles of carbon and phosphorus. Paleoceanography 9, 677-692.

Van Cappellen, P., Ingall, E.D., 1996. Redox stabilization of the atmosphere and oceans by phosphorus-limited marine productivity. Science 271, 493-496.

Van Cappellen, P., Ingall, E.D., 1997. Response to Comment 'Redox stabilization of the atmosphere and oceans and marine productivity' by Colman, A.S., F.T. Mackenzie, H.D. Holland. Science 275, 407-408.

Van Kaam-Peters, H.M.E., Schouten, S., Köster, J., Sinnighe Damsté, J.S.S., 1998. Controls on the molecular and carbon isotopic composition of organic matter deposited in a Kimmeridgian euxinic shelf sea: Evidence for preservation of carbohydrates through sulfurisation. Geochim. Cosmochim. Acta 62, 3259-3283.

Van Santvoort, P.J.M., De Lange, G.J., Thomson, J., Cussen, H., Wilson, T.R.S., Krom, M.D., Ströhle, K., 1996. Active post-depositional oxidation of the most recent sapropel (S1) in sediments of the eastern Mediterranean Sea. Geochim. Cosmochim. Acta 60, 4007-4024. 
Van Santvoort, P.J.M., De Lange, G.J., Langereis, C.G., Dekkers, M.J., Paterne, M., 1997. Geochemical and paleomagentic evidence for the occurrence of 'missing' sapropels in eastern Mediterranean sediments. Paleoceanography 12, 773-786.
Wignall, P.B., 1994. Black Shales. Clarendon Press, Oxford, 127 pp.

Williams, J.D.H., Mayer, T., Nriagu, J.O., 1980. Extractability of phosphorus from phosphate minerals common in soils and sediments. Soil Sci. Soc. Am. J. 44, 462-465. 